Review

\title{
An overview of carboxymethyl derivatives of chitosan: Their use as biomaterials and drug delivery systems
}

\author{
Bruno Fonseca-Santos, Marlus Chorilli* \\ School of Pharmaceutical Sciences, Department of Drugs and Medicines, UNESP-São Paulo State University, 14801-902 Araraquara, São Paulo, Brazil
}

\section{A R T I C L E I N F O}

\section{Article history:}

Received 7 November 2016

Received in revised form 21 February 2017

Accepted 21 March 2017

Available online 23 March 2017

\section{Keywords:}

Carboxymethyl chitosan

Biomaterials

Drug delivery

Nanotechnology

Medicine regenerative

Cosmetics

\begin{abstract}
A B S T R A C T
Chitin is one of the most abundant natural polymers in the world and is used for the production of chitosan by deacetylation. Chitosan is nontoxic and biodegradable and, therefore, can be used as a biomaterial and for the construction of drug delivery systems. Nevertheless, the poor solubility of chitosan in neutral or alkalinized media has restricted its applications in the pharmaceutical and biomedical fields. Chitosan can be easily carboxymethylated to improve its solubility in aqueous media while its biodegradability and biocompatibility are preserved. Carboxymethyl chitosans show improved solubility in aqueous media, which makes them an attractive alternative source for producing biomaterials and drug delivery systems as well as for designing nanotechnology-based systems. Thus, carboxymethyl chitosan-based materials have a wide applicability and good potential in the development of biomedical nanodevices and controlled release drug formulations. This review summarizes preparations and properties of hydrophilic chitosan-based materials such as nanoparticles, microparticles, tablets, and films as well as procedures related to various practical applications.
\end{abstract}

(c) 2017 Elsevier B.V. All rights reserved.

\section{Contents}

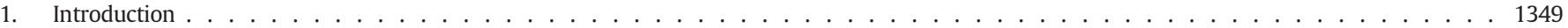

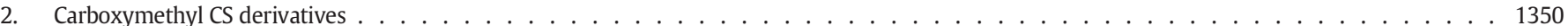

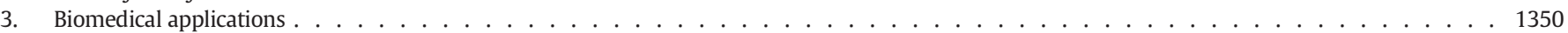

3.1. Uses in regenerative medicine. $\ldots 1350$

3.2. Use in wound healing . . . . . . . . . . . . . . . . . . . . . . . . . . . . . . . . . . . 1352

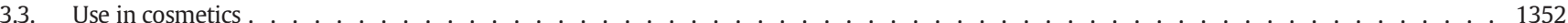

4. Drug delivery and nanotechnology-based systems . . . . . . . . . . . . . . . . . . . . . . . . . . . . . . . 1352

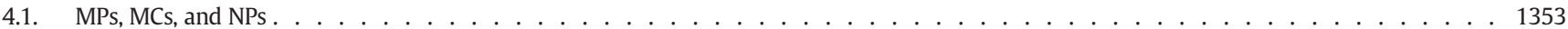

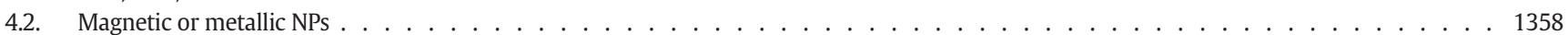

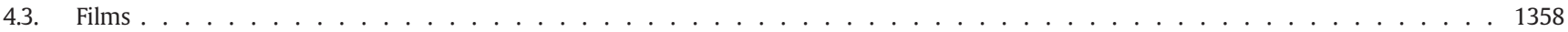

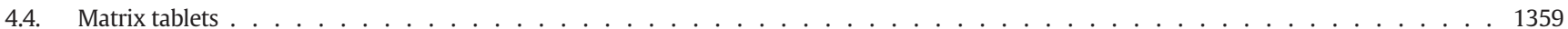

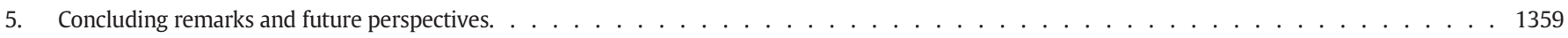

Author contributions. $\ldots \ldots \ldots \ldots$

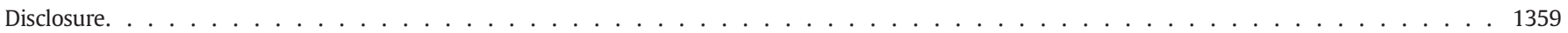

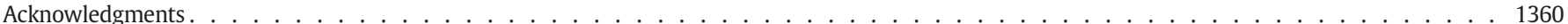

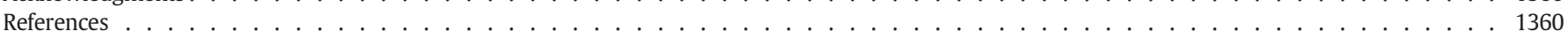

* Corresponding author at: Faculdade de Ciências Farmacêuticas, Departamento de Fármacos e Medicamentos, UNESP-Universidade Estadual Paulista, Rodovia AraraquaraJaú, 14801-902 Araraquara, São Paulo, Brazil.

E-mail address: chorilli@fcfar.unesp.br (M. Chorilli).

\section{Introduction}

Polymers, the most versatile class of materials, have changed our everyday lives over the past several decades. Nonetheless, there have been differences between the temporary and permanent biomedical 
applications of polymers over the last decades [1-3]. Natural polymers are usually biodegradable and offer excellent biocompatibility, but they vary between batches because of purification difficulties. In contrast, synthetic polymers with a wide variety of compositions and readily modifiable properties are available [4]. Bulk properties of polymers need to be considered for controlled delivery systems including molecular weight, adhesion, and solubility in aqueous media, which can affect the drug release mechanism, and the site of action [1,5].

Chitin $(\mathrm{CN})$ is found in the exoskeleton of crustaceans, the cell walls of fungi, and other biological materials. This natural polysaccharide, owing to its versatility, can be used as a flocculating agent for the treatment of wastewater, as an adsorbent for clarification of oils, and especially for the production of chitosan (CS) [6-8].

$\mathrm{CN}$ and $\mathrm{CS}$ (and its derivatives) have attracted attention as materials for use in pharmaceutical drug delivery systems [8-11]. The use of CS is limited by its low solubility in water, but this polymer is extensively used in drug delivery systems targeting major routes of administration $[9,12]$. CS can be formulated as derivatives with improved water solubility, thereby expanding its applications to the development of novel dosage forms or biomaterials [11,13-15].

CS is a linear polysaccharide composed of randomly distributed $\beta$ (1-4)-linked D-glucosamine and $N$-acetyl-D-glucosamine. CS is a cationic biopolymer produced from $\mathrm{CN}$, which is one of the most abundant biopolymers in nature after cellulose [9]. Although CS is insoluble in most organic solvents, it is readily soluble in dilute acidic solutions because it can be considered a strong base since it contains primary amino groups with a $\mathrm{pK}_{\mathrm{a}}$ value of 6.3. The presence of the amino groups indicates that $\mathrm{pH}$ substantially alters the charged state and properties of CS [16]. At low pH, these amines are protonated and become positively charged, making CS a water-soluble cationic polyelectrolyte [7].

Because of its low solubility at physiological pH (above 6.0), the use of CS as an enhancer of solubility and rate release of drugs is limited [13]. Furthermore, another limitation of CS in the preparation of sustainedrelease systems is its rapid adsorption of water and a higher swelling degree in aqueous environments, which can lead to rapid drug release [13]. To overcome these limitations, mainly the $\mathrm{pH}$-dependent solubility of CS, chemical modifications can be used to control the polymer-drug interaction, enhance the loading capability, improve the bulk properties of drug delivery systems, and control the drug release rate of the matrix $[13,17]$. For chemical modification, CS chains have three attractive reactive sites consisting of two hydroxyl groups (primary or secondary) and one primary amine group [18], and the modification of these groups will change the bulk properties of CS derivatives. The water solubility of carboxymethyl chitosan (CMCS) at various pH levels depends on the degree of carboxymethylation and has a strong effect on its aqueous solubility [19].

\section{Carboxymethyl CS derivatives}

The choice of the appropriate reaction conditions and reagents allows the preparation of $\mathrm{N}-, \mathrm{O}-, \mathrm{N}, \mathrm{O}-$, or $\mathrm{N}, \mathrm{N}$-carboxymethyl chitosan $[20,21]$. The carboxymethylation reaction with the OH group of carbon 2 of the CS structure has enabled researchers to generate derivatives that are soluble in both acidic and alkaline solutions [19]. However, the reactive sites for the carboxymethylation of CS are the amino and hydroxyl groups present in its chains. Thus, $O$-carboxymethyl chitosan (O-CMCS) is predominantly formed when the reaction is carried out at room temperature or in a cold bath, in an isopropanol/water suspension, and in the presence of monochloroacetic acid and sodium hydroxide $[19,22,23]$. Nonetheless, this reaction yields $N$-carboxymethyl chitosan (N-CMCS) and N,O-carboxymethyl chitosan (NO-CMCS) if carried out at higher temperatures [24-26]. In contrast, $\mathrm{N}-\mathrm{CMCS}$ and $\mathrm{N}, \mathrm{N}-$ (NN-CMCS) can be prepared by reacting CS with glyoxylic acid followed by reduction with sodium cyanoborohydride [27-29]. N-CMCS can also be obtained by direct alkylation [30] and the chemical structures of these polymers are shown in Fig. 1.
CS derivatives have been actively studied because of their physical, chemical, and biological properties such as high viscosity, low toxicity, superior bio/mucoadhesive properties, biocompatibility, and ability to form gels $[13,15,20,21,31,32]$. In addition, their suitability for the manufacture of tablets, films, and nanotechnology-based systems, as well as biomaterials for tissue engineering combined with their practicality, and the feasibility of production from commercial CS, and industrial scale-up have also made them a focus of research studies $[13,15,20,21$, 31,32].

In the last decade, there has been a large increase in the number of publications reporting the use of water-soluble derivatives of CS and their applications in biomedical and pharmaceutical fields (Fig. 2).

Therefore, based a search of databases and the compilation of articles published to date, this review article aims to highlight the main findings and discuss how this polymer is used in numerous biomedical and pharmaceutical areas, especially in drug delivery systems.

\section{Biomedical applications}

\subsection{Uses in regenerative medicine}

The utilization of polymer technologies is the most promising strategy for the regeneration of damaged tissues and organs. These nanoscale materials and cells directly interact with nanostructured extracellular matrices, nanobiomaterials such as nanofibers, nanotubes, nanoparticles (NPs), and other nanofabricated devices, which are capable of contributing to cell growth and tissue regeneration [33]. In this context, derivatives of CS have been used for tissue engineering and repair because of their promising properties.

The use of O-CMCS for the development of scaffolds with applicability to regenerative medicine has been attempted. Jaikumar et al. [34] developed injectable hydrogels made of alginate-O-CMCS-loaded fibrin NPs with proprieties suitable for adipose tissue engineering. These hydrogels are capable of swelling, which increases the pore size, thereby facilitating the infiltration of cells into the three-dimensional (3D) scaffolds. Another parameter studied was the degradability of polymeric matrices within 21 days, where these matrices lost weight before day 15 ( 20\% w/w loss) [34]. The authors suggested that this behavior is due to the crosslinks in the hydrogel microstructure. Hydrogel scaffolds were cultured with human adipose tissue-derived stem cells, and they supported cell growth, whereas the addition of fibrin NPs promoted cell adhesion and proliferation on the scaffold owing to their high surface to volume ratio.

Zhou et al. [35] developed a gelatin and O-CMCS-based scaffold using an irradiation cross-linking method that homogeneously distributed the $\beta$-tricalcium phosphate ( $\beta$-TCP) particles into the interconnected porous structure. The major result was that the material achieved the appropriate surface roughness to promote cell attachment, which is an important property of these types of materials for application in bone regeneration [36,37]. The evaluation of scaffold swelling including the examination of water uptake revealed it was directly dependent on the polymer concentration. This is an expected property because the amine and carboxyl groups interact with water via hydrogen bonds in the hydrogel, thereby favoring the swelling. The swelling profile showed that the maximum degree of swelling occurred at $30 \mathrm{~h}$; before this time point, solvent diffusion decreased, and hydrolysis was observed in the interior of the hydrogel domain, leading to the collapse of the hydrogel. In brief, the adjustable water retention capacity, the highly interconnected porous network structure, proper compressive strength, and high porosity can be used as criteria to determine the suitability for bone tissue regeneration. Furthermore, the biocompatibility of scaffolds was tested in vivo by implanting them in the mandible of beagle dogs. None of the tissue specimens showed wound infections, dropsies, necrosis, or serious inflammation. The results of the performance tests conducted using microcomputed tomography (micro-CT) showed that the volumetric density of the new bone formed 


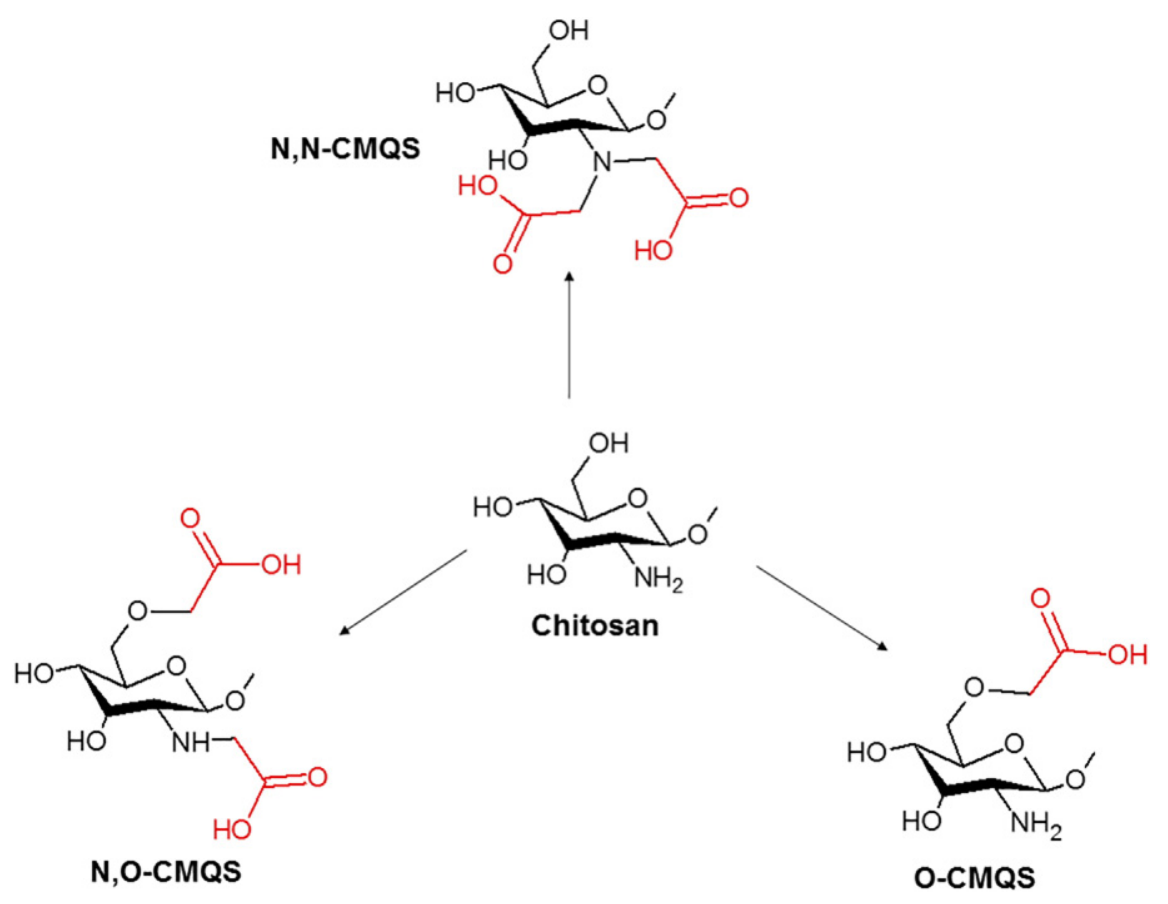

Fig. 1. Chemical structures of carboxymethyl derivatives of CS.

in the defects was 13.3 and $12.5 \%$ for scaffolds with and without $\beta$-TCP, respectively. These results indicate that O-CMCS and gelatin also enhance bone regeneration. The comprehensive results of this study suggest that scaffolds have a good potential as materials for bone tissue engineering.

In another study, Mishra et al. [38] designed O-CMCS, gelatin, and nanohydroxyapatite injectable gels for bone repair. The injection of these substances inside tissues induced in situ gelling and this jellification occurs because of the enzymatic cross-linking of gelatin and CS by tyrosinase to form a hydrogel. In addition, the use of $p$ cresol may increase the degree of cross-linking of the polymers. In that study, the gelling time was 35 min or less before the administration. An in vitro study of osteoblast proliferation and differentiation showed

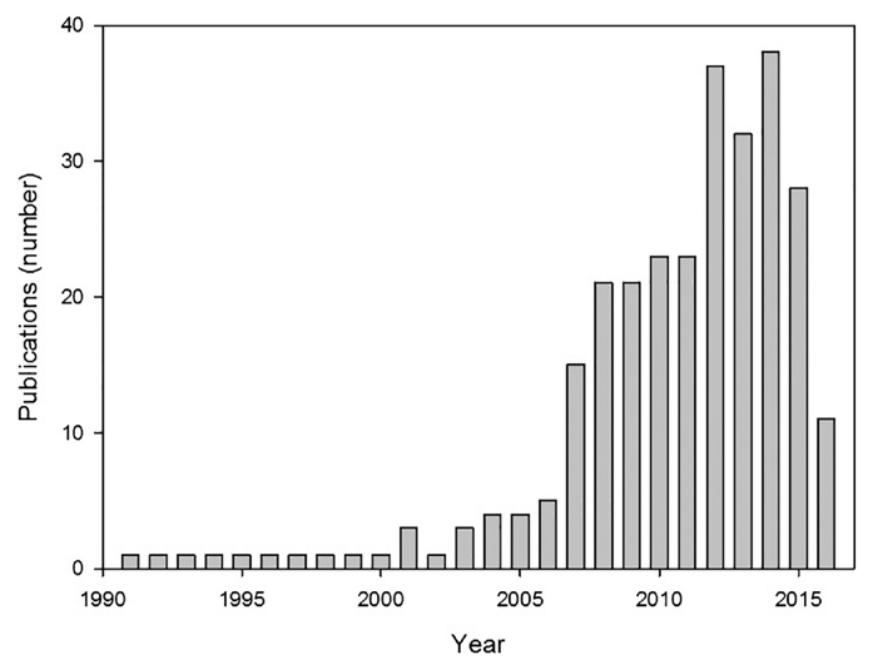

Fig. 2. Number of publications per year in the SCOPUS ${ }^{\circledR}$ database (all types of publications, e.g., letters, notes, conference proceedings, and articles), all areas of knowledge, with the main keywords "carboxymethyl chitosan", "biomaterial", and "drug delivery" in the article title, abstract, or keyword list. that all hydrogels support the growth of primary osteoblastic cells. The assessment of the in vivo stability of an injectable in situ gel in mice revealed no apparent signs of inflammation at the site of implantation, and its retrieval before implantation in the animals showed it had a gelatinous texture. Gel strength $\left(\mathrm{G}^{\prime}\right)$ values higher than $700 \mathrm{~Pa}$ in vitro can sufficiently retain the cross-linkage to form a solid gel in vivo. Thus, the oscillatory rheology can be used to predict the gel formation by injectable materials using their in situ gelling properties.

The use of CMCS derivatives was proposed for the prevention of postsurgical adhesions, which can impact a patient's subsequent health and is well known to cause impaired organ functioning, decreased fertility, bowel obstruction, difficulty with a reoperation, and possibly pain [39] or lead to morbidity and mortality [40]. NO-CMCS was studied in surgical models of (1) an abdominal aortic anastomosis, (2) a large bowel anastomosis, and (3) an abdominal skin incision. SpragueDawley rats were treated with NO-CMCS as a diluted dispersion and gel [41]. The results showed that the administration of the diluted dispersion before the operation did not significantly reduce adhesion formation, whereas application of both the gel and solution after the operation was the most efficacious [41]. One study using NO-CMCS postsurgically in two types of Sprague-Dawley rat abdominal surgery models, the uterine horn and small-bowel laceration models, showed a consistent reduction in the size, strength, and the number of adhesions in both models. Subsequently, Zhou et al. [42], Zhou et al. [43] investigated the use of NO-CMCS for the reduction of postsurgical adhesion formation after cardiac surgery in a rabbit model. Zhou et al. [42] concluded that the NO-CMCS gel and diluted dispersion significantly reduce the extent of postsurgical adhesion formation after cardiac surgery. The inability of fibroblasts to adhere to polymer surfaces suggests that NOCMCS may act as a biophysical barrier. Zheng et al. [44] studied the possible preventive effect of a CMCS antiadhesion solution on postsurgical adhesion. The histopathological analysis of male Wistar rats showed fewer inflammatory cells and fibroblasts. The effect of CMCS on the proliferation and collagen secretion of normal and keloid skin fibroblasts was reported by Chen et al. [45] who, in summary, demonstrated that the application of CMCS derivatives to presurgical lesions prevented tissue adhesion. These derivatives are known to have low toxicity and 
their effects on lesions support their use as a drug delivery platform for postsurgical injuries.

\subsection{Use in wound healing}

Wound healing is classically described as consisting of a series of processes, which are hemostasis, inflammation, proliferation, epithelization, maturation, and remodeling of the scar tissue [46,47]. The application of nanotechnology and polymers to wound healing is currently under evaluation in clinical studies. The current nanotechnological strategies, including carriers, films, drug delivery systems, and scaffolds can be used to improve wound healing [15,48-51].

The use of CS semisolid gels as wound healing accelerators has been reported, and their effects are due to the enhancement of inflammatory cell and fibroblasts function, which promotes tissue granulation and organization [52,53]. CS derivatives have shown to improve solubility or have new functions, which have extended their use beyond the present approaches to treating dermal lesions [54,55].

The use of NO-CMCS as a coating for wound-dressing cotton gauze was tested against infections with Escherichia coli and Staphylococcus aureus strains. The pad-dry-cure method was used to coat the cotton gauze surface with both polymers. A performance test conducted on albino rats to investigate the effects of the polymers on wound area closure indicated that polymer-coated gauze promoted the healing of the wounded rat skin [56]. The application of collagen matrixes and NOCMCS to wound dressings was investigated by culturing skin fibroblasts on matrices containing NO-CMCS, and the results showed increased proliferation and secretion of proinflammatory cytokines. An in vivo study of these matrices showed wound healing that was better than that of the control dressing [57]. This study supports the possible clinical application of such wound dressings.

CS and CMCS derivatives showed antibacterial activities against numerous microorganisms [58-60]. Microbes can preferentially infect wounds beneath the dressing materials and elicit serious infections that frequently require removal of the wound dressing. N-CMCS was a more effective bacteriostatic agent than CS was [55]. O-CMCS was also tested for antimicrobial activity, and the results suggest that its antibacterial activity depends on its molecular size [61].

A study by Loke et al. [62] reported that a dual layer of an O-CMCS hydrogel might act as a mechanical and microbial barrier and absorb wound exudates. Specifically, O-CMCS hydrogels swell considerably in physiological fluids and are highly porous to water vapor. In this study, the bottom layer of the hydrogels was loaded with chlorhexidine gluconate dispersed in acetate CS, an antimicrobial agent, and the 24-h release assays showed that the release rate depended on the polymer concentration. The developed films showed activity against Pseudomonas aeruginosa and S. aureus according to the Bauer-Kirby disk diffusion test. Wongpanit et al. [63] developed O-CMCS films cross-linked using microwave treatment and studied the in vitro adhesion of human fibroblast cells to their surfaces. These experiments showed the applicability of OCMCS films to wound healing.

\subsection{Use in cosmetics}

The use of CS derivatives based on their water solubility holds great promise in the field of cosmetics. The potential applications of CMCS derivatives in the production of cosmetics include moisture absorptionretention, antimicrobials, and emulsion stabilizing agents [20,64].

Exposure of the skin to ultraviolet (UV) radiation induces the formation of reactive oxygen species, leading to chronic inflammation and the breakdown of cell membranes in a process referred to as skin photoaging [65]. This process can lead to dry skin, which is a term used to describe the condition induced by a loss of water from the outermost stratum corneum (SC) layer of the skin [66]. Moisturizers have numerous effects on the skin including naturally hydrating the SC, which improves it and facilitates the desquamatory process in dry skin conditions $[67,68]$.

CS and its derivatives possess a positive electrical charge and relatively high molecular weight, which enables their adherence to the skin and subsequent skin moisturizing effects [69,70]. A $0.25 \% \mathrm{~N}-$ CMCS dispersion shows moisture retention that is comparable to that of a $20 \%$ aqueous solution of propylene glycol, and its viscosity is almost equal to that of hyaluronic acid (HA) [21]. Studies by Chen et al. [71,72] showed that moisture retention is dependent on the structural properties of polymers (e.g., the site of substitution, molecular weight, and degree of deacetylation) [71,72]. Moisture absorption and retention by $\mathrm{CM}$ derivatives of CS at different substitution sites (6-O-CMCS, 3,6-O-CMCS, or N-CMCS) and different molecular weights showed moistureabsorption abilities in the following descending order: 6-O-CMCS > 3,6-O-CMCS $>\mathrm{HA}>\mathrm{N}-\mathrm{CMCS}$ [71]. These findings indicate that the introduction of a $\mathrm{CM}$ group at the $\mathrm{C} 6$ position creates an active site for moisture absorption and retention, although carboxymethylation at the 3$\mathrm{OH}$ or $2-\mathrm{NH}_{2}$ positions is not essential. In contrast, the higher molecular weight also plays an important role in improving the moisture retention ability [71]. The intermolecular hydrogen bonds of the molecular chains may be a factor in regulating the moisture absorption and retention abilities of these derivatives [72].

Muzzarelli et al. [73] proposed the use of N-CMCS in cosmetic products for buccal applications such as toothpastes, mouthwashes, gingival gels, or artificial saliva formulations. The use of this polymer in buccal products has been explored because of its mucoadhesive properties $[74,75]$.

When intended for skin, CMCS gel formulations impart a feeling of smoothness to the skin and protect it from adverse environmental conditions and consequences of contact with detergents when applied [76].

\section{Drug delivery and nanotechnology-based systems}

A drug delivery system is defined as a formulation, dosage form, or device that enables the introduction of a drug, gene, or protein into the body and improves its efficacy and safety by controlling the rate, time, and place of drug release. This process includes administration of the product as well as the release of the drug or the subsequent transport of the drug delivery system across biological membranes to the site of action or both [77].

The process of drug release can be much more complex, potentially involving various processes: water diffusion into the system, polymer swelling, and drug dissolution, as well as polymer dissolution or degradation/erosion or both, in addition to the diffusion of dissolved drug molecules through a polymeric network or water-filled pores or both [78].

The use of polymers for the development of drug delivery systems is an attractive prospect because the release rate control of these systems is polymer-based. The drug release by these delivery systems can be classified as follows: diffusion-, swelling-, erosion-, and stimulusbased systems [79-81]. These mechanisms are shown in Fig. 3. Different types of mass transport processes can be involved in the control of the drug release from a dosage form $[1,82]$.

In diffusion-controlled release, a substance is released from a device by permeation from its interior to the surrounding medium $[83,84]$. Polymer chains such as those in a cross-linked hydrogel form the diffusion barrier [1]. In some cases, drug diffusion is the predominant step and in others, it plays a major role in combination with polymer swelling or polymer degradation or both, or matrix erosion $[84,85]$.

Swelling refers to the uptake of water by a polymer system with an increase in volume, and is often a prelude to polymer dissolution [83, 86]. The swelling process is analogous to osmosis because water penetrates the polymer relatively rapidly. However, when the dissolution of the polymer in water occurs, it is comparatively slow because of the polymer chains need to detangle. The extent of swelling depends on 


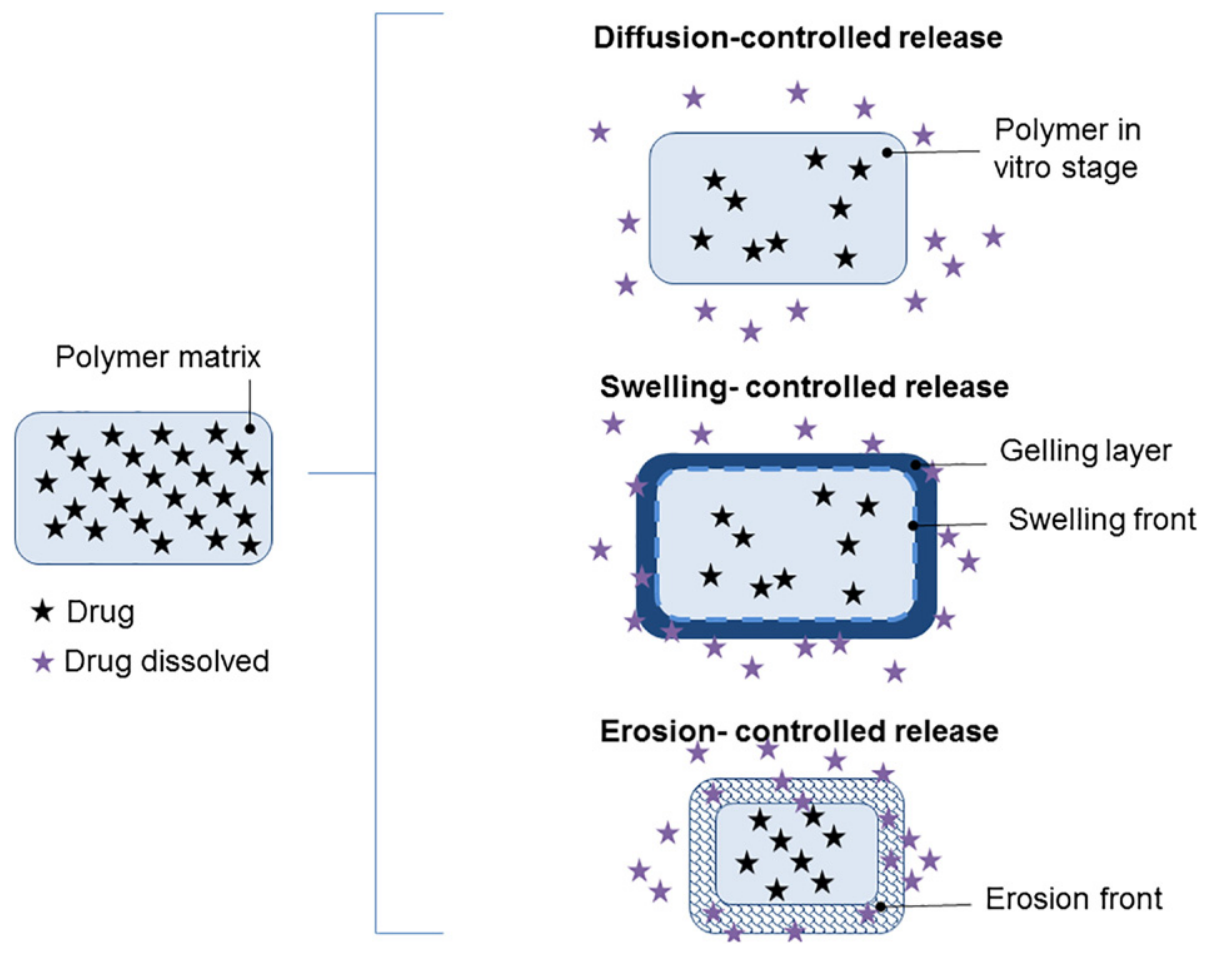

Fig. 3. Mechanisms of a drug release: diffusion, swelling, and erosion of a polymer matrix.

the hydrophilicity of the polymeric materials and the density of the crosslinks between polymer chains [87].

Erosion-controlled systems have gained popularity with the development of biodegradable polymers and involve a chemical or physical polymer or material loss to control drug delivery [87]. The erosion process involves the loss of material owing to monomers and oligomers leaving the polymer. Polymer erosion is far more complex than degradation is because it depends on many other processes such as swelling, the dissolution and diffusion of oligomers and monomers, and morphological changes in the matrix [88]. Depending on the composition of an erodible device (e.g., the type of polymer, drug loading, and additives) and geometry (size and shape), numerous mass transport phenomena and chemical reactions affect the resulting drug release kinetics [89].

The use of CMCS in these devices and pharmaceutical dosage forms can be useful because these polymers can control the release rate of drugs (as a result of advances in the drug delivery technology). This device achieves this control by ensuring that the therapeutic agents are released at constant doses over long periods, for both hydrophilic and hydrophobic drugs $[32,90]$. Some of these new platforms are shown in Table 1, e.g., microparticles (MPs) and NPs, microcapsules (MCs), tablets, and films, which are aimed at improving the bioavailability, pharmacokinetics, and pharmacodynamics of drugs while reducing their side effects or specific target organ and systemic toxicity.

\subsection{MPs, MCs, and NPS}

NPs and MPs are defined as particulate dispersions or solid particles with sizes ranging from 1 to $1000 \mathrm{~nm}$ or between 0.1 and 1000 $\mu \mathrm{m}$, respectively $[128,129]$. The boundary between micro- and nano-sizing is still a matter of debate [130]. The structural organization of a system is based on its composition: the presence of compartments within MCs or nanocapsules (NCs) results in oily or aqueous cores surrounded by thin polymer membranes, whereas micro- or nanospheres provide matrix-based organization of the polymeric chains [131-135] (Fig. 4).

Polymeric particles have been prepared using several methods including polymerization [136,137], ionic gelation or coacervation
[138,139], emulsion solvent evaporation [140-142], spontaneous emulsification or solvent diffusion [143,144], nanoprecipitation [141], spray drying [96,145], the supercritical fluid technology [146-148], and particle replication in nonwetting templates (PRINT) [149-152]. The choice of a production method is dependent on the type of polymer, its physicochemical properties, and drug solubility. The choice of a method may affect the physicochemical proprieties, particle size, and encapsulation efficiency of drugs, which may have an impact on the drug release profiles.

In recent years, drug delivery has expanded as a field of research, especially for CMCS as a carrier for various active biological compounds $[32,153]$. MPs or NPs are the main carrier systems for the delivery of drugs by CMCS-based systems [153]. CMCS-based microspheres, NPs, and micelles or aggregates can be created using different methods such as emulsion cross-linking, sonication, coacervation/precipitation, spray drying, ionic gelation, sieving, emulsion droplet-coalescence, and reverse micellar methods [32].

Poly(D,L-lactide-co-glycolic acid) (PLGA) and O-CMCS-encapsulated 5-fluorouracil (5-FU) NPs were synthesized using the water/oil/water (W/O/W) method The results of the characterization of these NPs showed that their mean size was $98.5 \mathrm{~nm}$, and 5-FU-loading was approximately $20 \%$. The release kinetics of 5 -FU from the NPs were shown to adhere to the Higuchi release equation for up to $12 \mathrm{~h}$ and, then, it corresponded to a zero-level release by 20 days [91].

CMCS NPs as carriers of the anticancer drug doxorubicin were created using ionic gelation [92]. In that study, the factors affecting NP formation were discussed in relation to the properties of CMCS. In this case, the authors suggested that a higher degree of substitution slightly improved the drug loading. In vitro release studies showed an initial burst ( $2 \mathrm{~h}$ ) followed by an extended slow release (until 3 days). The analysis of the influence of the molecular weight of CMCS on doxorubicin release behavior revealed that an increase in molecular weight could control the rate and amount of drug released. In contrast, increasing the degree of substitution of CMCS, decreased the release rate. The authors suggest that this phenomenon may be related to Coulombic interactions including hydrogen bonding and hydrophobic interactions that mediated the binding of the drug to the polymer [92]. A higher degree of 
Table 1

Summary of drug delivery and nanotechnology-based systems suitable for carboxymethyl chitosan (CMCS) derivatives.

\begin{tabular}{|c|c|c|c|c|c|c|}
\hline $\begin{array}{l}\text { Drug delivery } \\
\text { nanotechnology-based } \\
\text { systems }\end{array}$ & Formulation & $\begin{array}{l}\text { Method of } \\
\text { manufacture }\end{array}$ & $\begin{array}{l}\text { Drug or active } \\
\text { ingredient }\end{array}$ & Major applications & $\begin{array}{l}\text { Route of } \\
\text { administration }\end{array}$ & Reference \\
\hline \multirow[t]{23}{*}{$\begin{array}{l}\text { Polymeric } \\
\text { nanoparticles }\end{array}$} & PLGA/O-CMCS & $\begin{array}{l}\text { Emulsification } \\
\mathrm{W} / \mathrm{O} / \mathrm{W}\end{array}$ & $5-\mathrm{FU}$ & Controlled release of 5-FU up to 20 days & In vitro & [91] \\
\hline & O-CMCS & Ionotropic gelation & Doxorubicin & $\begin{array}{l}\text { Entrapment efficiency was enhanced from } \\
10 \text { to } 40 \% \text {. Release rate can be controlled } \\
\text { by MW and DS of polymer. }\end{array}$ & In vitro & {$[92]$} \\
\hline & CMCS & $\begin{array}{l}\text { Chelation under } \\
\text { aqueous conditions }\end{array}$ & Copper & $\begin{array}{l}\text { Estimated antibacterial activity against } \\
\text { Staphylococcus aureus was } 99 \%\end{array}$ & In vitro & [93] \\
\hline & PLA/O-CMCS & - & $\begin{array}{l}\text { Cultured } \\
\text { porcine } \\
\text { hepatocytes } \\
\text { embedded in } \\
\text { type I collagen }\end{array}$ & $\begin{array}{l}\text { No significant differences in serum } \\
\text { inflammatory markers. IgG levels were } \\
\text { lower after treatment. }\end{array}$ & $\begin{array}{l}\text { In vivo } \\
\text { Intraperitoneal }\end{array}$ & [94] \\
\hline & O-CMCS & Ionotropic gelation & - & $\begin{array}{l}\text { No toxicity against MCF- } 7 \text { cells. } \\
\text { Antibacterial activity tested against } \\
\text { S. aureus. }\end{array}$ & In vitro & {$[25]$} \\
\hline & NO-CMCS & Ionotropic gelation & - & $\begin{array}{l}\text { No toxicity against MCF- } 7 \text { cells. } \\
\text { Antibacterial activity tested against } \\
\text { S. aureus. }\end{array}$ & In vitro & {$[25]$} \\
\hline & NO-CMCS & Ionotropic gelation & Insulin & $\begin{array}{l}\text { Entrapment efficiency was } 50-75 \% \text {. } \\
\text { Release rate of insulin was influenced by } \\
\text { dissolution medium. }\end{array}$ & In vitro & {$[95]$} \\
\hline & $\mathrm{N}-\mathrm{CMCS}$ & $\begin{array}{l}\text { Ionotropic gelation } \\
\text { and co-spray-dryer }\end{array}$ & Idebenone & $\begin{array}{l}\text { Entrapment efficiency was }>90 \% \text {. } \\
\text { Nanoparticles (NPs) can protect the drug. } \\
\text { Preserved antioxidant activity in vitro. }\end{array}$ & In vitro & [96] \\
\hline & $\begin{array}{l}\text { Methoxy poly(ethylene } \\
\text { glycol)-grafted CMCS }\end{array}$ & $\begin{array}{l}\text { Ion complex } \\
\text { formation }\end{array}$ & Doxorubicin & $\begin{array}{l}\text { Ability to target loaded NPs to } \\
\text { doxorubicin-resistant glioma cells }\end{array}$ & In vitro & [97] \\
\hline & Folic acid modified CMCS & Sonication & Doxorubicin & $\begin{array}{l}\text { Ability to target loaded NPs to HeLa and } \\
\text { B16F1 cells }\end{array}$ & In vitro & {$[98]$} \\
\hline & $\begin{array}{l}\text { Folate conjugated } \\
\text { CMCS-manganese doped zinc } \\
\text { sulfide }\end{array}$ & Ionotropic gelation & 5-FU & $\begin{array}{l}\text { Able to induce a cytotoxic response to } \\
\text { MCF-7 cells. } \\
\text { Not toxic to mouse fibroblast L929 cells. } \\
\text { Folate receptor-mediated drug targeting } \\
\text { and imaging of cancer cells (MCF-7). }\end{array}$ & In vitro & [99] \\
\hline & CMCS/poly(amidoamine) & Precipitation & $\begin{array}{l}\text { Fluorescein } \\
\text { isothiocyanate }\end{array}$ & $\begin{array}{l}\text { Stable in circulation for up to } 72 \mathrm{~h} \text {. } \\
\text { Traces detected in the liver, lung, kidney, } \\
\text { and brain. } \\
\text { No changes in histological characteristics } \\
\text { of organs/tissues. }\end{array}$ & $\begin{array}{l}\text { Intravenous } \\
\text { route }\end{array}$ & {$[100]$} \\
\hline & O-CMCS & Dialysis method & Methotrexate & Sustained-release of drug & In vitro & [101] \\
\hline & Folic acid modified CMCS & Sonication & Doxorubicin & $\begin{array}{l}\text { Sustained-release of drug. } \\
\text { Targeting and cytotoxicity on HeLa cells. }\end{array}$ & In vitro & [102] \\
\hline & O-CMCS & Ionotropic gelation & Tetracycline & $\begin{array}{l}\text { NPs showed sustained release. } \\
\text { Able to induce cytotoxicity against } \\
\text { S. aureus in a targeted manner. }\end{array}$ & & [103] \\
\hline & O-CMCS & Ionotropic gelation & Metformin & $\begin{array}{l}\text { NPs showed nonspecific internalization by } \\
\text { normal and pancreatic cancer cells } \\
\text { (MiaPaCa-2). }\end{array}$ & In vitro & [104] \\
\hline & NO-CMCS & Ionotropic gelation & $5-\mathrm{FU}$ & $\begin{array}{l}\text { NPs showed blood compatibility. } \\
\text { Possible cellular internalization (uptake, } \\
\text { MCF-7 cell). } \\
\text { NPs showed toxicity against MCF-7 cells. }\end{array}$ & In vitro & [105] \\
\hline & O-CMCS & Ionic cross-linking & $\begin{array}{l}\text { Gentamicin } \\
\text { and salicylic } \\
\text { acid }\end{array}$ & $\begin{array}{l}\text { Drug entrapment above } 90 \% \text {. } \\
\text { Controlled release of drugs up to } 24 \mathrm{~h} \text {. } \\
\text { Drug release was governed by non-Fickian } \\
\text { or anomalous diffusion. }\end{array}$ & In vitro & [106] \\
\hline & CMCS-soy protein complex & $\begin{array}{l}\text { Ionic gelation } \\
\text { method }\end{array}$ & Vitamin D3 & $\begin{array}{l}\text { A drug was incorporated into the complex } \\
\text { nanoparticles. } \\
\text { Controlled release of vitamin D3. }\end{array}$ & In vitro & [107] \\
\hline & CMCS & $\begin{array}{l}\text { Ionic cross-linking } \\
\text { method }\end{array}$ & Ciprofloxacin & $\begin{array}{l}\text { Increase in MIC of a drug when it was } \\
\text { loaded into NPs. } \\
\text { Possibility of cellular uptake by E. coli } \\
\text { strains. }\end{array}$ & In vitro & [108] \\
\hline & CMCS & Ionotropic gelation & Metformin & $\begin{array}{l}\text { NPs reduced colony-forming ability of } \\
\text { cancer cells. } \\
\text { Normal biodistribution of NPs. } \\
\text { No changes in histological architecture of } \\
\text { organs. }\end{array}$ & $\begin{array}{l}\text { In vitro } \\
\text { In vivo } \\
\text { Intravenous } \\
\text { injection }\end{array}$ & [109] \\
\hline & O-CMCS/fucoidan & $\begin{array}{l}\text { Ionic cross-linking } \\
\text { method }\end{array}$ & Curcumin & $\begin{array}{l}\text { High encapsulation, control the release } \\
\text { and substantially increase the cellular } \\
\text { uptake of a drug }\end{array}$ & In vitro & [110] \\
\hline & CMCS & $\begin{array}{l}\text { Ultra-pressure } \\
\text { homogenization and } \\
\text { emulsion }\end{array}$ & Resveratrol & $\begin{array}{l}\text { Improved oral bioavailability compared to } \\
\text { free drug }\end{array}$ & $\begin{array}{l}\text { In vitro } \\
\text { In vivo } \\
\text { Oral }\end{array}$ & [111] \\
\hline
\end{tabular}


Table 1 (continued)

\begin{tabular}{|c|c|c|c|c|c|c|}
\hline $\begin{array}{l}\text { Drug delivery } \\
\text { nanotechnology-based } \\
\text { systems }\end{array}$ & Formulation & $\begin{array}{l}\text { Method of } \\
\text { manufacture }\end{array}$ & $\begin{array}{l}\text { Drug or active } \\
\text { ingredient }\end{array}$ & Major applications & $\begin{array}{l}\text { Route of } \\
\text { administration }\end{array}$ & Reference \\
\hline & & $\begin{array}{l}\text { cross-linking } \\
\text { method }\end{array}$ & & & administration & \\
\hline \multirow[t]{2}{*}{$\begin{array}{l}\text { Polymeric } \\
\text { microparticles }\end{array}$} & Alginate/CMCS & $\begin{array}{l}\text { Ionic cross-linking } \\
\text { method }\end{array}$ & - & $\begin{array}{l}\text { Controlled swelling rate compared to } \\
\text { unmodified chitosan (CS) }\end{array}$ & In vitro & [112] \\
\hline & CMCS & $\begin{array}{l}\text { Ionic cross-linking } \\
\text { method } \\
\text { Spray-dyer }\end{array}$ & Ketoprofen & Drug release from MPs was delayed & In vitro & [113] \\
\hline \multirow[t]{2}{*}{$\begin{array}{l}\text { Polymeric } \\
\text { microcapsules }\end{array}$} & NO-CMCS/alginate & $\begin{array}{l}\text { Electrostatic droplet } \\
\text { generation }\end{array}$ & BSA & $\begin{array}{l}\text { BSA release ratio of polymer-coated MCs } \\
\text { was lower than that of alginate MCs and } \\
\text { CS-coated MCs }\end{array}$ & In vitro & [114] \\
\hline & $\mathrm{N}-\mathrm{CMCS} /$ alginate & $\begin{array}{l}\text { Electrostatic spray } \\
\text { method } \\
\text { Genipin-cross-linked }\end{array}$ & - & $\begin{array}{l}\text { These MCs could be useful for drug } \\
\text { delivery }\end{array}$ & - & [115] \\
\hline \multirow[t]{3}{*}{$\begin{array}{l}\text { Magnetic } \\
\text { nanoparticles }\end{array}$} & $\mathrm{CMCS} / \mathrm{Fe}_{3} \mathrm{O}_{4}$ & Nanoprecipitation & - & $\begin{array}{l}\text { Superparamagnetism and high stability of } \\
\text { magnetization }\end{array}$ & - & [116] \\
\hline & $\mathrm{CMCS} / \mathrm{Fe}_{3} \mathrm{O}_{4}$ & $\begin{array}{l}\text { Nanoprecipitation } \\
\text { and spray-dryer }\end{array}$ & Camptothecin & $\begin{array}{l}\text { Better in vitro cancer inhibition activity } \\
\text { than that of a free drug }\end{array}$ & In vitro & [117] \\
\hline & CMCS/iron oxide & Coprecipitation & - & $\begin{array}{l}\text { In vitro disruption of } S \text {. aureus and } \\
\text { Escherichia coli biofilms }\end{array}$ & In vitro & [118] \\
\hline \multirow[t]{6}{*}{ Films } & $\mathrm{N}-\mathrm{CMCS}$ & Casting method & - & $\begin{array}{l}\text { This type of plasticizers showed lower } \\
\text { strength and a higher percentage } \\
\text { elongation. } \\
\text { N-CMCS films showed high tension and } \\
\text { lower elasticity than CS films did. }\end{array}$ & - & {$[27,119]$} \\
\hline & CMCS/PVA & Casting method & $\begin{array}{l}\text { Salicylic acid, } \\
\text { theophylline, } \\
\text { and Ornidazole }\end{array}$ & $\begin{array}{l}\text { Controlled drug release and swelling } \\
\text { properties }\end{array}$ & In vitro & {$[120]$} \\
\hline & CMCS/PVA & Casting method & Ornidazole & $\begin{array}{l}\text { Controlled drug release; } \\
\text { No toxic effects on periodontium and } \\
\text { tissues. } \\
\text { Antimicrobial activity. } \\
\text { Release of a drug implanted into tissue. }\end{array}$ & $\begin{array}{l}\text { In vitro } \\
\text { In vivo } \\
\text { Periodontal } \\
\text { administration } \\
\text { Tissue } \\
\text { implantation }\end{array}$ & {$[121]$} \\
\hline & $\mathrm{CS} / \mathrm{CMCS}$ & $\begin{array}{l}\text { Casting method with } \\
\text { cross-linking agent }\end{array}$ & Coenzyme $Q_{10}$ & $\begin{array}{l}\text { Cumulative release rate decreased with } \\
\text { drug loading content, ionic strength, or } \\
\text { more cross-linking agent. } \\
\text { Differences in rates and amounts of } \\
\text { released drugs may be attributed to } \\
\text { swelling behavior, degradation of films, } \\
\text { and interaction within drug-polymer } \\
\text { matrix. }\end{array}$ & In vitro & [122] \\
\hline & Sodium CM cellulose/HA/CMCS & $\begin{array}{l}\text { Extrusion/casting } \\
\text { method }\end{array}$ & - & Water absorption capability of films & In vitro & [123] \\
\hline & O-CMCS & $\begin{array}{l}\text { Casting/solvent } \\
\text { evaporation } \\
\text { technique }\end{array}$ & Tetracycline & $\begin{array}{l}\text { Suitable for controlled release due to film } \\
\text { treatments. } \\
\text { Antimicrobial activity was preserved, and } \\
\text { efficiency was dependent on the } \\
\text { treatment. }\end{array}$ & In vitro & [124] \\
\hline \multirow[t]{3}{*}{ Matrix tablets } & CMCS/2-hydroxyethylmethacrylate & $\begin{array}{l}\text { Wet granulation and } \\
\text { direct compression }\end{array}$ & Carbamazepine & $\begin{array}{l}\text { Ratio of the polymer influenced physical } \\
\text { proprieties and drug release of tablets }\end{array}$ & In vitro & {$[125]$} \\
\hline & CMCS & $\begin{array}{l}\text { Wet granulation and } \\
\text { direct compression }\end{array}$ & $\begin{array}{l}\text { Propranolol } \\
\text { hydrochloride }\end{array}$ & Controlled release of a drug & In vitro & [126] \\
\hline & O-CMCS & $\begin{array}{l}\text { Spray-drying of } \\
\text { polymer followed by } \\
\text { wet granulation or } \\
\text { direct compression }\end{array}$ & Diltiazem & $\begin{array}{l}\text { Controlled release of a drug dependent on } \\
\text { the polymer ratio } \\
\text { Direct compression tablets can control the } \\
\text { release compared to wet granulation } \\
\text { tablets }\end{array}$ & In vitro & [127] \\
\hline
\end{tabular}

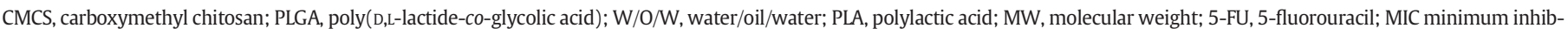
itory concentration; BSA, bovine serum albumin; IGg, immunoglobulin G; CM, carboxymethyl.

substitution in CMCS is expected to result in more compact NPs because a larger number of carboxyl groups of CM coordinate with calcium ions. Therefore, the release pattern of a drug from biodegradable NPs of CMCS can, therefore, be customized by choosing the molecular structure parameters such as molecular weight and characteristics of the chemical substitution [92].

Copper-loaded CMCS NPs were prepared using chelation under aqueous conditions [93]. The evaluation of the antibacterial activity on Staphylococcus aureus strains showed that the efficiency depended on the size of the NPs. Copper-loaded NPs ( $100 \mathrm{~nm})$ reached 99\% antibacterial activity, which is much more efficient than $68.9 \%$ copper-loaded
NPs with a size of approximately 1000 nm and 6.1\% NPs (without copper) [93]. These NPs proved to be a good novel antibacterial material. Some studies summarized the importance of NP size and electrostatic heterogeneity for bacterial adhesion [154-156]. Therefore, it appears that smaller particles can interact more efficiently with the bacterial cell than larger particles.

The effect of PLA (polylactic acid)-O-CMCS NPs on immunological rejection after an intraperitoneal porcine hepatocyte xenotransplant for the treatment of acute liver failure was studied in rats. The animals were intraperitoneally injected with D-galactosamine to induce acute hepatic failure and treated with porcine hepatocytes precultured with 

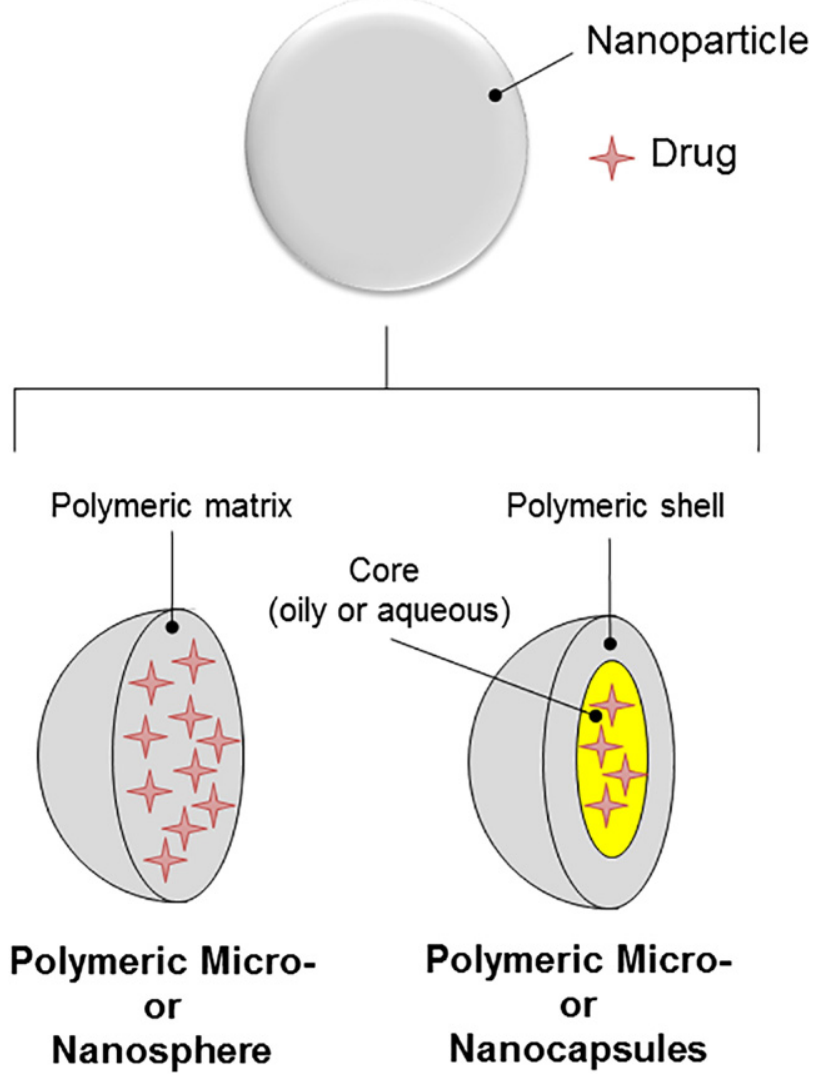

Fig. 4. Schematic differences between polymeric micro- or nanocapsules and micro- or nanoparticle drug delivery systems.

NPs and embedded in type I collagen. The major result was the absence of significant differences in serum interleukin (IL)-2 and interferon (IFN) $-\gamma$ levels among all the groups for 7 days post transplantation. Serum immunoglobulin G ( $\operatorname{IgG}$ ) levels in the nano-collagen hepatocyte group were lower than those in the collagen hepatocyte groups were. Thus, PLA-O-CMCS NPs can inhibit immunological rejection after an intraperitoneal porcine hepatocyte xenotransplant for the treatment of acute liver failure in rats [94].

NPs made of O-CMCS and N,O-CMCS were synthesized using simple ionic cross-linking using calcium chloride $\left(\mathrm{CaCl}_{2}\right)$ and sodium tripolyphosphate (TPP), respectively [25]. The cytotoxicity of the NPs was also determined using the 3-(4,5-dimethylthiazol-2-yl)-2,5-diphenyltetrazolium bromide (MTT) assay. This assay showed that the prepared NPs were less toxic to the MCF-7 breast cancer cell line. The major result was the demonstration of the antibacterial activities of these O-CMCS and NOCMCS NPs against $S$. aureus strains. The cytotoxicity of O-CMCS NPs was lower than that of the NO-CMCS NPs [25]. These findings suggest that this effect occurred because there was a higher degree of substitution of $\mathrm{CM}$ groups in the NO-CMCS than there was in the O-CMCS, which increased the antibacterial activity [157].

N,O-CMCS NPs were studied as an insulin carrier [95]. These systems were created using ionic gelation with TPP and exhibited particle sizes from 242 to $275 \mathrm{~nm}$ with encapsulation efficiency (\%) in the range of $75-50 \%$. The release studies showed that the insulin release was very rapid at an early stage, and the maximal release amount was $40-80 \%$ and $70-90 \%$ at pH 2.5 and 7.4, respectively. The authors concluded that in phosphate-buffered saline, the cumulative release of insulin from loaded NPs was greater and, thus, they could protect insulin from the acid [95].

$\mathrm{N}$-CMCS cross-linked with TPP were developed by codrying with idebenone. The efficiency of the drug incorporation was high (>80\%) and depended on the polymer ratio. In addition, the NPs showed a 10- fold increase in drug stability compared with that of the free drug and a preserved antioxidant activity in vitro. The agarose overlay test was performed and revealed that the idebenone-loaded NPs caused less membrane irritation than the severely irritant free drug. Thus, these NPs are promising carriers for hydrophobic and irritant drugs such as idebenone for topical or nasal use [96]. N-CMCS have mucoadhesive properties [158-163] and, therefore, these results suggest that NPs hold promise for use as carriers for the nasal delivery of hydrophobic drugs such as idebenone due to their high first-pass metabolism of idebenone [164] after oral administration.

Methoxy-poly(ethyleneglycol)-grafted CMCS was synthesized to form NPs carrying doxorubicin by the formation of an ionic complex. The particle size of the doxorubicin-loaded NPs was $\sim 300 \mathrm{~nm}$, and these NPs were spherical shaped. In an in vitro drug release study, higher drug content ensured the extended release of the drug, and this situation was significantly changed by the $\mathrm{pH}$ of the release medium. The drug release was faster at an acidic $\mathrm{pH}$ than it was at neutral or basic pH levels. The antitumor activity of doxorubicin-loaded NPs in vitro was tested on doxorubicin-resistant C6 glioma cells. NPs showed higher toxicity against tumor cells than the free drug did, indicating that doxorubicin-loaded NPs targeted doxorubicin-resistant C6 cells more effectively [97].

Folic-acid-modified CMCS NPs were prepared using sonication using a probe-type sonicator, and these NPs were conjugated with doxorubicin [98]. The NPs had an average size of $\sim 200 \mathrm{~nm}$ measured using dynamic light scattering and transmission electron microscopy. In vitro release profiles of doxorubicin from NPs at different $\mathrm{pH}$ levels showed that the drug release rates at $100 \mathrm{~h}$ were 40 and $60 \%$ at pH 7.4 and 5.0, respectively. These data can be explained as follows: the faster drug release rate in the lower $\mathrm{pH}$ medium could be attributed to the loose NP structure, which is caused by the stronger protonation of the amino groups of CMCS. Another reason is the higher solubility of doxorubicin at lower $\mathrm{pH}$ [98]. Those authors confirmed that the Fickian diffusion and polymer relaxation were the release mechanisms of this phenomenon. However, any mathematical model can be applied to the release profile of the drug to confirm this hypothesis. Folate-mediated targeting significantly enhances the cellular uptake of the NPs and, thereby, facilitates the apoptosis of cancer cells (HeLa and B16F1 lines) as confirmed using confocal microscopy and flow cytometric analysis [98].

Folate-conjugated CMCS-manganese-doped zinc sulfide NPs were developed by ionic cross-linking with $\mathrm{CaCl}_{2}$, and these NPs were coordinated to a manganese-doped zinc sulfide quantum dot [99]. The drug encapsulation efficiency was $92 \%$ at a polymer to 5 -FU ratio of $2: 1$. Analysis of the in vitro behavior of 5-FU release from NPs in PBS showed a sustained release of up to $90 \%$ for 6 days. The cytotoxicity assay results clearly indicated that the 5-FU encapsulated inside the NPs was able to cause toxic effects on MCF-7 cell lines and cell death was dependent on the concentration of the NPs. The in vitro imaging studies were performed on the MCF-7 breast cancer cell line, which expresses folate receptors on the cell surface. The results revealed that the NPs had a good binding affinity to the receptor in contrast to NPs without folate on their surface [99]. This is a promising result because these NPs alone can be used for targeted imaging of cancer cells.

CMCS/poly(amidoamine) dendrimer NPs showed lower levels of cytotoxicity than that of traditional dendrimers. In vivo biodistribution of fluorescein isothiocyanate (FITC)-labeled dendrimer NPs after intravenous injection in Wistar rats showed that these systems were stable in circulation for up to $72 \mathrm{~h}$, targeting the main systems through internalization by the cells. These results are suggestive of their potential for use as drug delivery systems in the future [100].

A novel drug carrier system combining a polymeric prodrug with nanotechnology was prepared. Specifically, methotrexate was conjugated to O-CMCS using amide links. This conjugate had amphiphilic properties and formed NPS in aqueous media by self-assembly. The release behaviors from NPs in buffer solutions were studied using the dynamic dialysis method. The results indicated significant sustained 
release, and the methotrexate-containing NPs released only $\sim 5.33-7.87 \%$ in $40 \mathrm{~h}$. The release rate decreased with an increasing methotrexate content of the conjugates. The authors believe that this effect can be explained as follows: NPs with the higher drug content had more densely packed hydrophobic microdomains, which were formed by aggregation of the drug [101]. Furthermore, this situation made it more difficult for the drug to transfer to the aqueous media [101].

Doxorubicin-loaded folic acid modified CMCS NPs were synthesized using the sonication method. The in vitro release profile of doxorubicin from the NPs showed an initial burst release phase, followed by a sustained release phase. The cellular uptake of these NPs was found to be higher than that of NPs based on linoleic-acid-modified CMCS because of the folic acid receptor-mediated endocytosis; the superior uptake ensured higher cytotoxicity against the HeLa cells [102].

In another study, tetracycline-loaded O-CMCS NPs were prepared using ionic cross-linking with $\mathrm{CaCl}_{2}$. The encapsulation efficiency of the drug, which was found to be $\sim 70 \%$, increased in a polymer ratio dependent manner. These NPs were capable of intracellular drug delivery and showed a six-fold increase in antibacterial activity against $S$. aureus, comparison with that of the free drug. These NPs could also be used for the treatment of other bacterial diseases caused by Chlamydiae, Mycoplasma, Rickettsia, and protozoa [103].

Another group prepared metformin-loaded O-CMCS NPs using the ionic gelation method. The major results were as follows: the in vitro drug release profile of metformin showed an initial burst release of the surface-adsorbed drug, followed by a slow and sustained release of the entrapped drug. These NPs did not induce any hemolysis and, therefore, proved to be hemocompatible. These NPs showed nonspecific uptake by both normal and pancreatic cancer cells and dose-dependent preferential toxicity against pancreatic cancer cells [104].

5-FU-loaded N,O-CMCS NPs were synthesized using ionotropic gelation with TPP. The drug entrapment efficiency was $~ 65 \%$, and in vitro drug release experiments revealed that $~ 92 \%$ of the drug was released from the 5-FU solution within $24 \mathrm{~h}$. The 5-FU-loaded NPs showed an initial burst release followed by a sustained release of the drug over a period of 6 days. The authors stated that the initial burst release could be due to the surface adsorbed drug while the sustained release occurred because of the slow degradation of the carrier matrix. Cellular internalization, i.e., nonspecific uptake of the drug-loaded NPs was observed in MCF-7 breast cancer cells. Anticancer activity, apoptosis, and caspase 3 assays proved the toxicity of the drug-loaded NPs against breast cancer cells. These systems showed blood compatibility in the in vitro hemolytic and coagulation assays [105].

O-CMCS NPs loaded with gentamicin and salicylic acid were prepared, characterized, and their in vitro drug release was studied. These NPs were prepared using the ionic cross-linking method. The characterization studies showed a spherical morphology with particle size ranging from 148 to $345 \mathrm{~nm}$. The salicylic acid and gentamicin entrapment efficiency rates were $\sim 90$ and $95 \%$, respectively. The in vitro release experiments performed at $\mathrm{pH} 7.4$ in phosphate buffer revealed a burst drug release in the first $1 \mathrm{~h}$, followed by the controlled release of the drugs for up to $24 \mathrm{~h}$. The release profiles were fitted to the Korsmeyer-Peppas model and these results suggests that the $n$ values of both drugs were $<0.5$, indicating that the drug release was governed by a non-Fickian or anomalous diffusion [106].

Vitamin D3 was encapsulated into CMCS-soy protein complex NPs using ionic gelation. The efficiency of encapsulation was $84-96 \%$ for vitamin D3. The release experiments showed that $<35 \%$ of the drug was released in the simulated gastric fluid containing the NPs. When the CMCS-containing samples were transferred to the simulated intestinal fluid ( $\mathrm{pH} 7.4$ ), they became negatively charged and, therefore, soluble. As a result, up to $83 \%$ of the remaining vitamin $\mathrm{D}$ was released from the polymeric matrix over the following $4 \mathrm{~h}$. Based on this phenomenon, the authors suggested that these complex NPs robustly protect the drug against digestion by gastric juices, and subsequently increased the amount of drug delivered to the simulated intestinal fluid [107].
CMCS NPs for the delivery of ciprofloxacin were prepared using the ionic cross-linking method and were characterized. The minimum inhibitory concentration (MIC) of the NPs against E. coli was analyzed. The results showed that the MICs of the free ciprofloxacin and ciprofloxacin-loaded NPs were 160 and $80 \mathrm{mg} / \mathrm{mL}$, respectively, and there was a phagocytosis effect in the presence of these NPs. The authors concluded that these NPs have a stronger antibacterial activity against $E$. coli than the free ciprofloxacin does because they can easily be delivered to cells [108].

The in vitro anticancer effect and in vivo biodistribution and biocompatibility of metformin-loaded O-CMCS NPs were evaluated for possible use as a pancreatic cancer therapy. The O-CMCS-metformin NPs attenuated tumor formation and induced apoptosis of MiaPaCa- 2 cells. The in vivo biodistribution of metformin-NPs was imaged by tracking the near infrared (NIR) fluorescence of the dye at different time intervals. The major results revealed that the NPs had a normal biodistribution pattern, which was comparable to that of the free indocyanine green (dye) without any significant in vivo accumulation. No changes were observed in the histopathological analysis, which showed that animal organs such as the spleen, liver, kidneys, brain, lungs, and heart had a normal cellular architecture [109].

Curcumin-loaded O-CMCS/fucoidan NPs were developed to increase the cellular curcumin uptake. These NPs are interesting because they remain intact at $\mathrm{pH} 2.5$, swell noticeably as the $\mathrm{pH}$ increases to 6.0 , and at $\mathrm{pH} 7.4$, the structure is disrupted. This phenomenon indicates the $\mathrm{pH}$ sensitivity of the NPs, which may be interesting for developing controlled drug delivery systems. The investigation of the cellular uptake of the NPs Caco-2 cells revealed that the curcumin-loaded NPs were located in the cytoplasm surrounding the nuclei after being internalized by the cells [110]. The system can potentially be used in oral delivery applications and to control the release of hydrophobic compounds.

CMCS NPs were formulated using emulsion the cross-linking method. In vitro release experiments simulating the human gastrointestinal tract were performed on resveratrol and resveratrol-CMCS NPs, and the results revealed burst and sustained release periods. The cumulative release was $81 \%$ and $64 \%$ in 68 h for simulated gastric and intestinal fluids, respectively, which was higher than that of the free resveratrol. The drug release profile was analyzed and showed a better fit to the Higuchi model than it did to other models. In vivo oral bioavailability studies in rats showed that the area under the curve (AUC) of the NPs was 3.5-fold greater than that obtained following administration of the free drug. The loading of the drug into the NPs prevented its removal from the body and decreased the clearance rate, whereas the elimination half-life significantly increased. These phenomena extended the duration of the presence of the drug in the body and improved its bioavailability [111].

Core-shell alginate/CMCS MPs were formulated with a spherical or spheroidal shape and a particle size $(2.1-7.0 \mu \mathrm{m})$ that depended on the solution $\mathrm{pH}$ and chemical nature of the polymer. The average particle size, degree of swelling, thermal stability, and zeta potential of the hydrogels were evaluated. The hydrogels had the smallest MPs and showed the lowest degree of swelling when they were exposed to the simulated gastric fluid. The major outcome was that the modification of CS with CM groups ensured there was less swelling in the simulated gastric fluid, which is a desired characteristic for sustained release that prevents gastric burst release of the drug before it reaches the intestines [112].

Ketoprofen-loaded CMCS MPs were formulated using ionic gelation and the resulting MPs were spray-dried using a standard method. The particle size under different spray-drying conditions was 1.40-2.10 $\mu \mathrm{m}$ and the efficiency of encapsulation was $~ 90 \%$. The simulated intestinal fluid medium at $\mathrm{pH} 6.8$ showed a drug release rate of $\sim 90,60$, and $50 \%$ for the free drug, high-polymer ratio MPs, and low-polymer ratio MPs, respectively. Therefore, ketoprofen release from the MPs was delayed by up to 0.43 -fold compared to that of the free ketoprofen [113].

A 2-hour study of the BSA release profiles from alginate MCs, CScoated MCs, and N,O-CMCS-coated MCs in an acidic medium (pH 2.0) 
revealed the BSA release ratio of N,O-CMCS-coated MCs ( 18\%) was lower than that of the alginate $(\sim 33 \%)$ and CS-coated ( 23\%) MCs. At $\mathrm{pH} 7.0$, the BSA release ratio of the O-CMCS-coated MCs ( 54\%) was similar to that of the alginate MCs $(\sim 55 \%)$ and higher than that of the CS-coated MCs ( 43\%). These results showed that the $\mathrm{pH}$-responsive properties of the N,O-CMCS-coated MCs were better than those of the alginate and CS-coated MCs [114].

In another study, genipin-crosslinked N-CMCS and alginate MCs were formulated using the electrostatic spray method. These microspheres have a uniform diameter with a smooth surface and a coreshell structure. This report suggests that these MCs are potentially useful for drug delivery [115].

\subsection{Magnetic or metallic NPS}

Magnetic NPs offer some attractive application possibilities in biomedicine. Especially, in cancer therapy where the use of a magnetic-NP system under the influence of an external magnetic field to target and deliver NPs has received much attention due to its simplicity, ease of preparation, and the possibility of customizing the properties for specific cancer applications [165-167].

CMCS NPs with magnetic properties may be used as a drug carrier, especially to target cancer cells. CMCS-coated ferric chloride $\left(\mathrm{Fe}_{3} \mathrm{O}_{4}\right)$ NPs were formulated using a coprecipitation method, and the saturated magnetization of the NPS could reach $25.73 \mathrm{emu} / \mathrm{g}$. The NPs also showed the characteristics of superparamagnetism and high stability of magnetization [116].

Camptothecin-loaded $\mathrm{Fe}_{3} \mathrm{O}_{4}$ NPs were coated using O-CMCS and the nanoprecipitation technique used was freeze-drying. The in vitro release not only depended on the size of the NPs but also on the physicochemical properties of the polymer. The cytotoxicity test on liver cancer cells showed that the drug-loaded modified $\mathrm{Fe}_{3} \mathrm{O}_{4} \mathrm{NPs}$ had better in vitro inhibitory activity against cancer cells than the free drug did [117]. While this study is quite interesting, the release studies are not valid because they were carried out in phosphate buffer, which does not simulate the sink condition. Camptothecin is poorly soluble in water (hydrophobic), and the lactone form is poorly soluble in the buffer [168]. Accordingly, surfactants are added to the dissolution media to maintain sink conditions during dissolution testing of controlled-release systems for water-insoluble drugs [169-172].

The disruption of biofilms of $S$. aureus and $E$. coli was studied using a non-antibiotic-based strategy for disrupting biofilms using CMCS-coated magnetic iron oxide NPs. The number of viable cells in S. aureus and E. coli biofilms after exposure to these NPs in a magnetic field decreased by 84 and 95\%, respectively, after $48 \mathrm{~h}$. In contrast, the NPs were highly effective against planktonic $S$. aureus and $E$. coli strains, and $>99 \%$ of the cells died following a 10- and 5-hour exposure, respectively [118].

\subsection{Films}

$\mathrm{N}$-CMCS films were formulated using the casting method at polymer concentrations of 1 and $2 \%$ with or without a plasticizer (polyethylene glycol [PEG] 400 or glycerol at 15\%). The plasticizer presence yielded lower strength and a higher percentage elongation than its absence did, in the following order: glycerol > polyethylene glycol $400>$ unplasticized film. However, the water vapor transmission rate increased with increasing polymer concentration. Nonetheless, PEG 400 films appeared to be more suitable for barrier film applications than the other films were owing to their weaker effect on water saturation and vapor permeability, considering its pharmaceutical uses as a physical barrier [119]. The analysis of CS and N-CMCS films showed that the CMCS films supported high tension with lower elasticity. N-CMCS has a more compact film structure than that of the CS films, as determined using scanning electron microscopy [27].

A high CMCS content in CMCS-poly(vinyl alcohol) (PVA) blend films may cause roughness of the surface and decrease the strength. The swelling rate indicated that the CMCS/PVA blend films showed a pHdependent swelling behavior and swelled significantly at high $\mathrm{pH}$; the swelling degree decreased sharply with decreasing $\mathrm{pH}$. This result is crucial for the development of coating materials from these substances, which showed improved characteristics following the addition of this polymer. Three model drugs (salicylic acid, theophylline, and omidazole) were studied using a static diffusion vessel, and their release followed zero-order kinetics [120]. In addition, an increase in the CMCS content of the blend films caused a fast drug release rate while blend films with a high PVA content showed a slow drug release rate [120].

Omidazole-loaded PVA/CMCS blend films were studied as a potential local drug delivery system. The thickness of the films was $\sim 200$ $\mu \mathrm{m}$, and the surface was heterogeneous. All the films swelled rapidly and reached equilibrium within $30 \mathrm{~min}$ in the $\mathrm{pH} 7$ medium. A low degree of swelling was observed under acidic conditions, but high swelling was registered at a high $\mathrm{pH}$. In vitro release experiments showed that almost $100 \%$ of the drug was released from CMCS films within 60 min, but only $30 \%$ was released from the PVA film within the same time. For the blend films, the drug release rate was moderate; faster than the release rate of PVA films but slower than that of CMCS films. The in vitro antimicrobial assays performed against E. coli and S. aureus showed a more potent inhibition of $E$. coli than of $S$. aureus at high concentrations of CMCS. However, these systems had antimicrobial effects. Toxicity against the periodontium of Wistar rats was evaluated, and no changes in hyperemia, turgidity, disruption, or ulceration in the periodontium were observed. The systems were implanted in rats to analyze the inflammatory tissue response for 1 to 4 weeks. The major results indicated that the blend film was eroded and degraded during subcutaneous implantation and did not have any adverse effects [121].

Films based on CS and CM-CS were formulated using glutaraldehyde as a cross-linking agent. The cumulative release rate of the drug decreased with increasing loading content, ionic strength, or crosslinking agent amount. The authors suggested that the release of the drug was controlled by the swelling behavior of the film and, therefore, the drug release may be related to an erosive process. In contrast, the amount of drug released from the films decreased with increasing cross-linker concentration at $\mathrm{pH} 2.1$, which was attributed to the swelling behavior of the cross-linked network. At low concentrations of the cross-linking agent, the density of the cross-linking was low, which caused the film to swell extensively [122].

Blend films based on sodium CM-cellulose, hyaluronic acid (HA), and CMCS were developed, and the investigation of their water absorption capability revealed it increased as a function of the HA/CMCS ratio [123]. The authors stated that the improvement in water absorption was due to the excellent water-retention ability at an appropriate ratio of HA/CMCS, and opined that this is an important factor for the hygroscopicity of films. In designing wound dressing systems intended for application to the surface of injured tissue, hydrophilicity is an important characteristic of films for local treatment [123].

O-CMCS films (1\% polymer) were produced using a casting/solvent evaporation technique. Tetracycline delivery systems were prepared by dissolving $1 \mathrm{~g}$ polymer and tetracycline (100 and $200 \mathrm{mg}$ ) in $100 \mathrm{~mL}$ of distilled water. The solution was then poured into a Teflon ${ }^{\circledR}$ mold (with a diameter of $5.0 \mathrm{~cm}$ ) and allowed to evaporate at $50{ }^{\circ} \mathrm{C}$ for $72 \mathrm{~h}$ to form a film, which was cut into a disk shape with a diameter and area of $4.7 \mathrm{~mm}$ and $0.17 \mathrm{~cm}^{2}$, respectively. These films were treated with glutaraldehyde cross-linked films or heat-treated at 90,120 , or $150^{\circ} \mathrm{C}$ for $4 \mathrm{~h}$. Water uptake assays showed a decrease for films loaded with 100 and $200 \mathrm{mg}$ of the drug, suggesting that the drug possibly protects the $\mathrm{NH}_{2}$ groups of the polymer, thereby preventing cross-linking. In contrast, heat treatment of the system decreased the water absorption in proportion with the temperature increase. Furthermore, heat treatment enhanced the water resistance and reduced the aqueous solubility by inducing the formation of cross-links between O-CMCS molecules in the films. In vitro drug release assays showed that almost 85 and $48 \%$ of the drug was released from the heattreated and cross-linked films after $8 \mathrm{~h}$, respectively. Drug permeation in 
the O-CMCS films occurs mainly via the pore mechanism and depends on the ionization of the O-CMCS films and the drug diffusion. All the films were better fitted to the Peppas model than they were to other models, with diffusion exponents between 0.11 and 0.46 , which indicates a nonFickian or anomalous diffusion mechanism of release. In vitro antimicrobial experiments showed that the films had a bacteriostatic activity against S. aureus, due to the release of the antimicrobial agent for up to $72 \mathrm{~h}$. In addition, after $96 \mathrm{~h}$, the microbial growth was so intense that the colonies could not be counted further. The antimicrobial activity of the tetracycline was preserved, and its efficacy depended on the treatment the films were subjected to. The results revealed that the O-CMCS film could serve as a possible matrix for the treatment of infectious diseases that require the local release of an antimicrobial agent, e.g., periodontitis [124].

\subsection{Matrix tablets}

Hydrophilic matrix systems are used for oral controlled drug delivery because they ensure a desirable drug profile and are more cost effective than other systems [173]. The mechanism of drug release from hydrophilic matrices involves polymer swelling following contact with the aqueous medium, which forms a gel layer on the surface of the system; then, the drug is released by dissolution, diffusion, erosion, or a combination of these processes [174-177].

CMCS grafted with 2-hydroxyethylmethacrylate was designed to formulate carbamazepine-loaded matrix tablets using the wet granulation technique. The effect of the binding agent (graft copolymer) on properties such as hardness, friability, and dissolution was studied. Increasing the amount of the binding agent in the tablets decreased friability, increased hardness, and slightly reduced the average weight of each tablet. Increasing the concentration of the binder decreased the drug release because at higher binder concentrations, the gelling properties of the binder increased. Subsequently, the diffusion of the drug from the highly swollen network becomes difficult and, therefore, the drug release rate is slower at higher binder concentrations [125].

Propanolol-loaded CMCS matrix tablets were formulated using wet granulation and then, direct compression. Analysis of the physical properties of the matrix tablets showed low friability, which indicates they were compact and hard. Analysis of the in vitro release of a drug showed a release rate of $\sim 40 \%$ in gastric fluid media. Then, a slow release rate was observed in an intestinal fluid medium, indicating the controlled release of the drug. The dissolution profiles showed that the controlled release of propranolol hydrochloride from the tablet followed the Korsmeyer-Peppas model [126].

Spray-dried O-CMCS was formulated using the spray-drying technique with the following drying conditions: inlet temperature, $170{ }^{\circ} \mathrm{C}$; aspiration rate, 90\%; airflow, 480 normal liters per minute; air pressure, 5 bars; and sample flow, 4-6 mL/min. The tablets were prepared using direct compression and wet granulation methods and contained $90 \mathrm{mg}$ diltiazem as well as excipients to ensure a tablet weight of $500 \mathrm{mg}$ [127]. In the direct compression method, the powders were mixed and then the compression process was carried out using a rotary compressing machine using circular, concave 12-mm punctures. The wet granulation method involved passing O-CMCS, microcrystalline cellulose, and the drug through a $350-\mathrm{mm}$ sieve, and then they were mixed, wetted with water, granulated using a $1-\mathrm{mm}$ sieve, and then dried in an oven at $40^{\circ} \mathrm{C}$ for $24 \mathrm{~h}$. After the granules had been standardized using the $1-\mathrm{mm}$ sieve, a lubricant was added to the tablets obtained by the direct compression method. The matrix tablets formulated using the direct compression method were white with a smooth, bright, physically homogeneous appearance. The analysis of the internal matrix morphology revealed spherical, practically unchanged O-CMCS MPs, which were not deformed by the compression process. In contrast, the wet granulation method produced tablets with an irregular surface, smooth internal structure, and no observed O-CMCS particles [127]. There was a direct relationship between the proportion of O-CMCS and the release of diltiazem, swelling, and water uptake; a greater amount of O-
CMCS resulted in a true swelling-controlled system. The direct compression tablets containing 80 and $50 \%$ O-CMCS showed a better fit to the zero-order mathematical model than to other models. A formulation containing $30 \%$ of the polymer showed a better fit to the Higuchi and Korsmeyer-Peppas kinetic models than it did to other models. The diffusion mechanism was predominant in the kinetic analysis using the Peppas and Sahlin model. The tablets produced using wet granulation showed a worse fit to the kinetics models than to other models, probably because the tablets no longer exhibited matrix behavior. Matrices have shown high rates of swelling and water uptake, and this pattern did not erode the matrix. Furthermore, the matrices produce sufficient polymer efficiency to form a hydrophilic swelling matrix that is resistant to erosion, thereby allowing its application as a matrix for the sustained release of drugs [127].

\section{Concluding remarks and future perspectives}

This review summarized chemically modified CS targeted for use as in biomaterials, drug delivery systems, and nanotechnology devices. While the use of CMCS has expanded in recent decades, this may have been limited because it has to be synthesized, in contrast to CS, which is an easily obtained pharmaceutical ingredient. Although these derivatives are produced by organic synthesis, the process is easy and produces good yields. The production of such derivatives does not require expensive pharmaceutical ingredients and reagents and, therefore, industrial scale production is extremely feasible.

The use of such derivatives as biomedical materials is promising and includes their use in surgery and regenerative medicine (especially in bone repair and wound healing), and many of the related studies were conducted in vivo. The research is relevant to trauma-related processes and the improvement of wound healing, regardless of chronic and other predisposing conditions such as pressure and diabetic ulcers, as well as various cardiovascular conditions.

Drug delivery systems also appear to be interesting because of the practical applicability of these modified polymers. Solubility is an important characteristic for modulating drug release and changing production processes that generate materials with appropriate mechanical properties (e.g., films). The design of delivery systems using derivatives of CS occurs at the micro- and nano-technological interfaces where it is possible to produce NPs, MPs, and NCs. In addition, films and solid dosage forms such as matrix tablets may also be produced using CS derivatives. Most of these studies were focused on drug release tests, which clearly showed the effective control of drug release. Few studies have been conducted in animal models, especially biodistribution or pharmacokinetic studies; however, cellular studies have revealed that these systems showed good properties. The minority of studies performed in mammalian models have shown that CS-derived delivery systems are nontoxic and biocompatible. Therefore, it is possible to control the release of drugs and increase their solubility or absorption, which subsequently increases or maintains pharmacodynamic and biological responses. Moreover, these studies show the enormous potential these polymers have for use in drug delivery systems.

The use of these polymer derivatives is increasing in the research and development of biomaterials and drug delivery systems, and these advances could be remarkable and will manifest themselves in new publications in the coming years.

\section{Author contributions}

BFS made substantial contributions to conceiving the idea for this review, searching the bibliographical data, conducting the analysis, and critically revising it for important intellectual content. MC conducted the analysis and revised the text critically for important intellectual content. Both coauthors approved the final version of the text for publication.

\section{Disclosure}

The authors report no conflicts of interest associated with this work. 


\section{Acknowledgments}

The authors are grateful to the São Paulo Research Foundation-FAPESP (Grant number: 14/24180-0 and 15/05394-2) for a research fellowship to BFS and Programa de Apoio ao Desenvolvimento Científico da Faculdade de Ciências Farmacêuticas da UNESP (PADC-FCF-UNESP) for financial support.

\section{References}

[1] K.E. Uhrich, S.M. Cannizzaro, R.S. Langer, K.M. Shakesheff, Polymeric systems for controlled drug release, Chem. Rev. 99 (1999) 3181-3198.

[2] A. Aghabegi Moghanjoughi, D. Khoshnevis, A. Zarrabi, A concise review on smart polymers for controlled drug release, Drug Deliv. Transl. Res. 6 (2016) 333-340.

[3] S.D. Bruck, Medical applications of polymeric materials, Med. Prog. Technol. 9 (1982) 1-16.

[4] N. Angelova, D. Hunkeler, Rationalizing the design of polymeric biomaterials, Trends Biotechnol. 17 (1999) 409-421.

[5] O. Pillai, R. Panchagnula, Polymers in drug delivery, Curr. Opin. Chem. Biol. 5 (2001) 447-451.

[6] M. Rinaudo, Chitin and chitosan: properties and applications, Prog. Polym. Sci. 31 (2006) 603-632.

[7] C.K.S. Pillai, W. Paul, C.P. Sharma, Chitin and chitosan polymers: chemistry, solubility and fiber formation, Prog. Polym. Sci. 34 (2009) 641-678.

[8] M.N.V. Ravi Kumar, A review of chitin and chitosan applications, React. Funct. Polym. 46 (2000) 1-27.

[9] A. Bernkop-Schnürch, S. Dünnhaupt, Chitosan-based drug delivery systems, Eur. J. Pharm. Biopharm. 81 (2012) 463-469.

[10] O. Felt, P. Buri, R. Gurny, Chitosan: a unique polysaccharide for drug delivery, Drug Dev. Ind. Pharm. 24 (1998) 979-993.

[11] N.M. Alves, J.F. Mano, Chitosan derivatives obtained by chemical modifications for biomedical and environmental applications, Int. J. Biol. Macromol. 43 (2008) 401-414.

[12] I.M. van der Lubben, J.C. Verhoef, G. Borchard, H.E. Junginger, Chitosan and its derivatives in mucosal drug and vaccine delivery, Eur. J. Pharm. Sci. 14 (2001) 201-207.

[13] M. Prabaharan, Review paper: chitosan derivatives as promising materials for controlled drug delivery, J. Biomater. Appl. 23 (2008) 5-36.

[14] K. Aiedeh, M.O. Taha, Synthesis of chitosan succinate and chitosan phthalate and their evaluation as suggested matrices in orally administered, colon-specific drug delivery systems, Arch. Pharm. 332 (1999) 103-107.

[15] C. Choi, J.-P. Nam, J.-W. Nah, Application of chitosan and chitosan derivatives as biomaterials, J. Ind. Eng. Chem. 33 (2016) 1-10.

[16] H. Yi, L.-Q. Wu, W.E. Bentley, R. Ghodssi, G.W. Rubloff, J.N. Culver, G.F. Payne, Biofabrication with chitosan, Biomacromolecules 6 (2005) 2881-2894.

[17] K. Yao, J. Li, F. Yao, Y. Yin, Chitosan-based Hydrogels: Functions and Applications, CRC Press, 2011.

[18] R. Riva, H. Ragelle, A. des Rieux, N. Duhem, C. Jérôme, V. Préat, Chitosan and chitosan derivatives in drug delivery and tissue engineering, in: R. Jayakumar, M. Prabaharan, R.A.A. Muzzarelli (Eds.), Chitosan for Biomaterials II, Springer Berlin Heidelberg 2011, pp. 19-44.

[19] X.-G. Chen, H.-J. Park, Chemical characteristics of O-carboxymethyl chitosans related to the preparation conditions, Carbohydr. Polym. 53 (2003) 355-359.

[20] V.K. Mourya, N.N. Inamdar, A. Tiwari, Carboxymethyl chitosan and its applications, Adv. Mater. Lett. 1 (2010) 11-33.

[21] R.A.A. Muzzarelli, Carboxymethylated chitins and chitosans, Carbohydr. Polym. 8 (1988) 1-21.

[22] U. Shinde, M.H. Ahmed, K. Singh, Development of dorzolamide loaded 6-Ocarboxymethyl chitosan nanoparticles for open angle glaucoma, J. Drug Deliv. 2013 (2013) 15

[23] C.A. Demarchi, A. Debrassi, F. de Campos Buzzi, R. Correa, V.C. Filho, C.A. Rodrigues, N. Nedelko, P. Demchenko, A. Slawska-Waniewska, P. Dluzewski, J.-M. Greneche, A magnetic nanogel based on $O$-carboxymethylchitosan for antitumor drug delivery: synthesis, characterization and in vitro drug release, Soft Matter 10 (2014) 3441-3450.

[24] S.-C. Chen, Y.-C. Wu, F.-L. Mi, Y.-H. Lin, L.-C. Yu, H.-W. Sung, A novel pH-sensitive hydrogel composed of $\mathrm{N}, \mathrm{O}$-carboxymethyl chitosan and alginate cross-linked by genipin for protein drug delivery, J. Control. Release 96 (2004) 285-300.

[25] A. Anitha, V.V. Divya Rani, R. Krishna, V. Sreeja, N. Selvamurugan, S.V. Nair, H. Tamura, R. Jayakumar, Synthesis, characterization, cytotoxicity and antibacterial studies of chitosan, $\mathrm{O}$-carboxymethyl and $\mathrm{N}, \mathrm{O}$-carboxymethyl chitosan nanoparticles, Carbohydr. Polym. 78 (2009) 672-677.

[26] W.E.G. Muller, E. Tolba, H.C. Schroder, M. Neufurth, S. Wang, T. Link, B. Al-Nawas, X Wang, A new printable and durable $\mathrm{N}, \mathrm{O}$-carboxymethyl chitosan- $\mathrm{Ca}^{2+}$-polyphosphate complex with morphogenetic activity, J. Mater. Chem. B 3 (2015) 1722-1730.

[27] M.E.S. Miranda, C. Marcolla, C.A. Rodrígues, H.M. Wilhelm, M.R. Sierakowski, T.M.B. Bresolin, R.A de Freitas, Chitosan and $\mathrm{N}$-carboxymethylchitosan: I. The role of $\mathrm{N}$ carboxymethylation of chitosan in the thermal stability and dynamic mechanical properties of its films, Polym. Int. 55 (2006) 961-969.

[28] H.P. Bassani, F. Valenga, M.R. Sierakowski, R.A.d. Freitas, Formation, drug-release kinetics and solution-stability of $\mathrm{N}$-acetyl- $\mathrm{N}$-carboxymethyl chitosan nanoparticles as potential drug carriers, Int. J. Drug Deliv. 5 (2013) 214-223.

[29] R.A. de Freitas, M.F. Drenski, A.M. Alb, W.F. Reed, Characterization of stability, aggregation, and equilibrium properties of modified natural products; the case of carboxymethylated chitosans, Mater. Sci. Eng. C 30 (2010) 34-41.
[30] N.T. An, P.L. Dung, D.T. Thien, N.T. Dong, T.T.Y. Nhi, An improved method for synthesizing $N, N^{\prime}$-dicarboxymethylchitosan, Carbohydr. Polym. 73 (2008) 261-264.

[31] F.R.d. Abreu, S.P. Campana-Filho, Preparation and characterization of carboxymethylchitosan, Polímeros 15 (2005) 79-83.

[32] L. Upadhyaya, J. Singh, V. Agarwal, R.P. Tewari, The implications of recent advances in carboxymethyl chitosan based targeted drug delivery and tissue engineering applications, J. Control. Release 186 (2014) 54-87.

[33] J. Danie Kingsley, S. Ranjan, N. Dasgupta, P. Saha, Nanotechnology for tissue engineering: need, techniques and applications, J. Pharm. Res. 7 (2013) 200-204.

[34] D. Jaikumar, K.M. Sajesh, S. Soumya, T.R. Nimal, K.P. Chennazhi, S.V. Nair, R Jayakumar, Injectable alginate-O-carboxymethyl chitosan/nano fibrin composite hydrogels for adipose tissue engineering, Int. J. Biol. Macromol. 74 (2015) 318-326.

[35] Y. Zhou, L. Xu, X. Zhang, Y. Zhao, S. Wei, M. Zhai, Radiation synthesis of gelatin/CMchitosan/ $\beta$-tricalcium phosphate composite scaffold for bone tissue engineering, Mater. Sci. Eng. C 32 (2012) 994-1000.

[36] R.A.A. Muzzarelli, Chitosan composites with inorganics, morphogenetic proteins and stem cells, for bone regeneration, Carbohydr. Polym. 83 (2011) 1433-1445.

[37] J. Li, Y. Dou, J. Yang, Y. Yin, H. Zhang, F. Yao, H. Wang, K. Yao, Surface characterization and biocompatibility of micro- and nano-hydroxyapatite/chitosan-gelatin network films, Mater. Sci. Eng. C 29 (2009) 1207-1215.

[38] D. Mishra, B. Bhunia, I. Banerjee, P. Datta, S. Dhara, T.K. Maiti, Enzymatically crosslinked carboxymethyl-chitosan/gelatin/nano-hydroxyapatite injectable gels for in situ bone tissue engineering application, Mater. Sci. Eng. C 31 (2011) 1295-1304.

[39] M.P. Diamond, M.L. Freeman, Clinical implications of postsurgical adhesions, Hum. Reprod. Update 7 (2001) 567-576.

[40] R.P.G. ten Broek, C. Strik, Y. Issa, R.P. Bleichrodt, H. van Goor, Adhesiolysis-related morbidity in abdominal surgery, Ann. Surg. 258 (2013) 98-106.

[41] D.J. Costain, R. Kennedy, C. Ciona, V.C. McAlister, T.D.G. Lee, Prevention of postsurgical adhesions with $\mathrm{N}, \mathrm{O}$-carboxymethyl chitosan: examination of the most efficacious preparation and the effect of $\mathrm{N}, \mathrm{O}$-carboxymethyl chitosan on postsurgical healing, Surgery 121 (1997) 314-319.

[42] J. Zhou, R.S. Liwski, C. Elson, T.D.G. Lee, Reduction in postsurgical adhesion formation after cardiac surgery in a rabbit model using $\mathrm{N}, \mathrm{O}$-carboxymethyl chitosan to block cell adherence, J. Thorac. Cardiovasc. Surg. 135 (2008) 777-783.

[43] J. Zhou, J.M. Lee, P. Jiang, S. Henderson, T.D.G. Lee, Reduction in postsurgical adhesion formation after cardiac surgery by application of $\mathrm{N}, \mathrm{O}$-carboxymethyl chitosan, J. Thorac. Cardiovasc. Surg. 140 (2010) 801-806.

[44] Z. Zheng, W. Zhang, W. Sun, X. Li, J. Duan, J. Cui, Z. Feng, H. Mansour, Influence of the carboxymethyl chitosan anti-adhesion solution on the TGF- $\beta 1$ in a postoperative peritoneal adhesion rat, J. Mater. Sci. Mater. Med. 24 (2013) 2549-2559.

[45] X.-G. Chen, Z. Wang, W.-S. Liu, H.-J. Park, The effect of carboxymethyl-chitosan on proliferation and collagen secretion of normal and keloid skin fibroblasts, Biomaterials 23 (2002) 4609-4614.

[46] A.J. Singer, R.A.F. Clark, Cutaneous wound healing, N. Engl. J. Med. 341 (1999) 738-746.

[47] G.C. Gurtner, S. Werner, Y. Barrandon, M.T. Longaker, Wound repair and regeneration, Nature 453 (2008) 314-321.

[48] I. Tocco, B. Zavan, F. Bassetto, V. Vindigni, Nanotechnology-based therapies for skin wound regeneration, J. Nanomater. 2012 (2012) 11.

[49] P.S. Murphy, G.R.D. Evans, Advances in wound healing: a review of current wound healing products, Plast. Surg. Int. 2012 (2012)

[50] G.E.J. Poinern, D. Fawcett, Y.J. Ng, N. Ali, R.K. Brundavanam, Z.T. Jiang, Nanoengineering a biocompatible inorganic scaffold for skin wound healing, J. Biomed. Nanotechnol. 6 (2010) 497-510.

[51] J.S. Boateng, K.H. Matthews, H.N.E. Stevens, G.M. Eccleston, Wound healing dressings and drug delivery systems: a review, J. Pharm. Sci. 97 (2008) 2892-2923.

[52] H. Ueno, T. Mori, T. Fujinaga, Topical formulations and wound healing applications of chitosan, Adv. Drug Deliv. Rev. 52 (2001) 105-115.

[53] T. Dai, M. Tanaka, Y.-Y. Huang, M.R. Hamblin, Chitosan preparations for wounds and burns: antimicrobial and wound-healing effects, Expert Rev. Anti-Infect. Ther. 9 (2011) 857-879.

[54] A. Francesko, T. Tzanov, Chitin, chitosan and derivatives for wound healing and tissue engineering, in: G.S. Nyanhongo, W. Steiner, G. Gübitz (Eds.), Biofunctionalization of Polymers and Their Applications, Springer Berlin Heidelberg 2011, pp. 1-27.

[55] R. Jayakumar, M. Prabaharan, S.V. Nair, S. Tokura, H. Tamura, N. Selvamurugan, Novel carboxymethyl derivatives of chitin and chitosan materials and their biomedical applications, Prog. Mater. Sci. 55 (2010) 675-709.

[56] B. Venkatrajah, V.V. Malathy, B. Elayarajah, R. Rajendran, R. Rammohan, Synthesis of carboxymethyl chitosan and coating on wound dressing gauze for wound healing, Pak. J. Biol. Sci. 16 (2013) 1438-1448.

[57] R.-N. Chen, G.-M. Wang, C.-H. Chen, H.-O. Ho, M.-T. Sheu, Development of N,O(carboxymethyl)chitosan/collagen matrixes as a wound dressing, Biomacromolecules 7 (2006) 1058-1064.

[58] R.C. Goy, D.d. Britto, O.B.G. Assis, A review of the antimicrobial activity of chitosan, Polímeros 19 (2009) 241-247.

[59] F. Seyfarth, S. Schliemann, P. Elsner, U.C. Hipler, Antifungal effect of high- and lowmolecular-weight chitosan hydrochloride, carboxymethyl chitosan, chitosan oligosaccharide and $\mathrm{N}$-acetyl-D-glucosamine against Candida albicans, Candida krusei and Candida glabrata, Int. J. Pharm. 353 (2008) 139-148.

[60] M. Kong, X.G. Chen, K. Xing, H.J. Park, Antimicrobial properties of chitosan and mode of action: a state of the art review, Int. J. Food Microbiol. 144 (2010) 51-63.

[61] J. Tantala, M. Thongngam, P. Rachtanapun, C. Rachtanapun, Antimicrobial activity of chitosan and carboxymethyl chitosan from diferent types and sources of chitosan, Ital. J. Food Sci. 24 (2012) 97-101.

[62] W.-K. Loke, S.-K. Lau, L.L. Yong, E. Khor, C.K. Sum, Wound dressing with sustained antimicrobial capability, J. Biomed. Mater. Res. 53 (2000) 8-17. 
[63] P. Wongpanit, N. Sanchavanakit, P. Pavasant, P. Supaphol, S. Tokura, R. Rujiravanit, Preparation and characterization of microwave-treated carboxymethyl chitin and carboxymethyl chitosan films for potential use in wound care application, Macromol. Biosci. 5 (2005) 1001-1012.

[64] A. Jimtaisong, N. Saewan, Utilization of carboxymethyl chitosan in cosmetics, Int. J. Cosmet. Sci. 36 (2014) 12-21.

[65] S. Pillai, C. Oresajo, J. Hayward, Ultraviolet radiation and skin aging: roles of reactive oxygen species, inflammation and protease activation, and strategies for prevention of inflammation-induced matrix degradation-a review, Int. J. Cosmet. Sci. 27 (2005) 17-34.

[66] Z.D. Draelos, Cosmetic Dermatology: Products and Procedures, second ed. WileyBlackwell, Oxford, 2016.

[67] A.V. Rawlings, P.J. Matts, Stratum corneum moisturization at the molecular level: an update in relation to the dry skin cycle, J. Invest. Dermatol. 124 (2005) 1099-1110.

[68] J. Polaskova, J. Pavlackova, P. Vltavska, P. Mokrejs, R. Janis, Moisturizing effect of topical cosmetic products applied to dry skin, J. Cosmet. Sci. 64 (2013) 329-340.

[69] P.K. Dutta, J. Dutta, V.S. Tripathi, Chitin and chitosan: chemistry, properties and applications, J. Sci. Ind. Res. 63 (2004) 20-31.

[70] V. Venugopal, in: S.-K. Kim (Ed.), Cosmeceuticals From Marine Fish and Shellfish, CRC Press, Boca Raton 2012, pp. 211-232.

[71] L. Chen, Y. Du, H. Wu, L. Xiao, Relationship between molecular structure and moisture-retention ability of carboxymethyl chitin and chitosan, J. Appl. Polym. Sci. 83 (2002) 1233-1241.

[72] L. Chen, Y. Du, X. Zeng, Relationships between the molecular structure and moisture-absorption and moisture-retention abilities of carboxymethyl chitosan: II. Effect of degree of deacetylation and carboxymethylation, Carbohydr. Res. 338 (2003) 333-340.

[73] R. Muzzarelli, M. Cucchiara, C. Muzzarelli, $N$-carboxymethyl chitosan in innovative cosmeceutical products, J. Appl. Cosmetol. 20 (2002) 201-208.

[74] J. das Neves, B. Sarmento, Mucosal Delivery of Biopharmaceuticals: Biology, Challenges and Strategies, Springer, New York, 2014.

[75] C. Feng, J. Li, M. Kong, Y. Liu, X.J. Cheng, Y. Li, H.J. Park, X.G. Chen, Surface charge effect on mucoadhesion of chitosan based nanogels for local anti-colorectal cancer drug delivery, Colloids Surf. B: Biointerfaces 128 (2015) 439-447.

[76] R.A.A. Muzzarelli, C. Muzzarelli, Chitosan chemistry: relevance to the biomedica sciences, in: T. Heinze (Ed.), Polysaccharides I: Structure, Characterisation and Use, Springer-Verlag Berlin Heidelberg 2005, pp. 151-209.

[77] K.K. Jain, Drug delivery systems-an overview, in: K.K. Jain (Ed.), Drug Delivery Systems, Humana Press, Totowa, NJ 2008, pp. 1-50.

[78] J. Siepmann, F. Siepmann, Mathematical modeling of drug dissolution, Int. J. Pharm. 453 (2013) 12-24.

[79] C.-C. Lin, A.T. Metters, Hydrogels in controlled release formulations: network design and mathematical modeling, Adv. Drug Deliv. Rev. 58 (2006) 1379-1408.

[80] D.Y. Arifin, L.Y. Lee, C.-H. Wang, Mathematical modeling and simulation of drug release from microspheres: implications to drug delivery systems, Adv. Drug Deliv. Rev. 58 (2006) 1274-1325.

[81] C.d.l.H. Alarcon, S. Pennadam, C. Alexander, Stimuli responsive polymers for biomedical applications, Chem. Soc. Rev. 34 (2005) 276-285.

[82] B. Narasimhan, N.A. Peppas, Molecular analysis of drug delivery systems controlled by dissolution of the polymer carrier, J. Pharm. Sci. 86 (1997) 297-304.

[83] R.W. Baker, Controlled Release of Biologically Active Agents, Wiley, New York, 1987.

[84] X. Huang, C.S. Brazel, On the importance and mechanisms of burst release in matrix-controlled drug delivery systems, J. Control. Release 73 (2001) 121-136.

[85] J. Siepmann, F. Siepmann, Modeling of diffusion controlled drug delivery, J. Control. Release 161 (2012) 351-362.

[86] R.S. Harland, A. Gazzaniga, M.E. Sangalli, P. Colombo, N.A. Peppas, Drug/polymer matrix swelling and dissolution, Pharm. Res. 5 (1988) 488-494.

[87] R.A. Siegel, M.J. Rathbone, Overview of controlled release mechanisms, in: ]. Siepmann, R.A. Siegel, M.J. Rathbone (Eds.), Fundamentals and Applications of Controlled Release Drug Delivery, Springer, New York 2012, pp. 19-43.

[88] A. Göpferich, Mechanisms of polymer degradation and erosion, Biomaterials 17 (1996) 103-114.

[89] J. Siepmann, A. Göpferich, Mathematical modeling of bioerodible, polymeric drug delivery systems, Adv. Drug Deliv. Rev. 48 (2001) 229-247.

[90] W.B. Liechty, D.R. Kryscio, B.V. Slaughter, N.A. Peppas, Polymers for drug delivery systems, Annu. Rev. Chem. Biomol. Eng. 1 (2010) 149-173.

[91] Y.X. Hu, X.B. Yuan, Y. Guo, J. Chang, C.X. Song, The degradation and release behavior of 5-fluorouracil-loaded PLGA/O-CMC nanoparticles in vitro, Chin. J. Biomed. Eng. 24 (2005) 492-497.

[92] X. Shi, Y. Du, J. Yang, B. Zhang, L. Sun, Effect of degree of substitution and molecular weight of carboxymethyl chitosan nanoparticles on doxorubicin delivery, J. Appl Polym. Sci. 100 (2006) 4689-4696.

[93] C. Gu, B. Sun, W. Wu, F. Wang, M. Zhu, Synthesis, characterization of copper-loaded carboxymethyl-chitosan nanoparticles with effective antibacterial activity, Macromol. Symp. 254 (2007) 160-166.

[94] Z. Chen, H.Y. Cai, F. Tang, W.J. Guan, Effect of polylactic acid-O-carboxymethylated chitosan nanoparticles on immunological rejection in intraperitoneal porcine hepatocyte xenotransplantation of rats, J. Clin. Rehabil. Tissue Eng. Res. 12 (2008) 6287-6291.

[95] C.C. Lin, C.W. Lin, Preparation of N,O-carboxymethyl chitosan nanoparticles as an insulin carrier, Drug Deliv. 16 (2009) 458-464.

[96] C.d.M. Amorim, A.G. Couto, D.J.A. Netz, R.A. de Freitas, T.M.B. Bresolin, Antioxidant idebenone-loaded nanoparticles based on chitosan and $\mathrm{N}$-carboxymethylchitosan, Nanomed. Nanotechnol. Biol. Med. 6 (2010) 745-752.
[97] Y.-I. Jeong, S.-G. Jin, I.-Y. Kim, J. Pei, M. Wen, T.-Y. Jung, K.-S. Moon, S. Jung, Doxorubicin-incorporated nanoparticles composed of poly(ethylene glycol)grafted carboxymethyl chitosan and antitumor activity against glioma cells in vitro, Colloids Surf. B: Biointerfaces 79 (2010) 149-155.

[98] S.K. Sahu, S.K. Mallick, S. Santra, T.K. Maiti, S.K. Ghosh, P. Pramanik, In vitro evaluation of folic acid modified carboxymethyl chitosan nanoparticles loaded with doxorubicin for targeted delivery, J. Mater. Sci. Mater. Med. 21 (2010) 1587-1597.

[99] M.E. Mathew, J.C. Mohan, K. Manzoor, S.V. Nair, H. Tamura, R. Jayakumar, Folate conjugated carboxymethyl chitosan-manganese doped zinc sulphide nanoparticles for targeted drug delivery and imaging of cancer cells, Carbohydr. Polym. 80 (2010) 442-448

[100] V.H. Pereira, A.J. Salgado, J.M. Oliveira, S.R. Cerqueira, A.M. Frias, J.S. Fraga, S. Roque, A.M. Falcão, F. Marques, N.M. Neves, J.F. Mano, R.L. Reis, N. Sousa, In vivo biodistribution of carboxymethylchitosan/poly(amidoamine) dendrimer nanoparticles in rats, J. Bioact. Compat. Polym. 26 (2011) 619-627.

[101] Y. Wang, X. Yang, J. Yang, Y. Wang, R. Chen, J. Wu, Y. Liu, N. Zhang, Self-assembled nanoparticles of methotrexate conjugated $O$-carboxymethyl chitosan: preparation, characterization and drug release behavior in vitro, Carbohydr. Polym. 86 (2011) 1665-1670.

[102] Y.L. Tan, C.G. Liu, Preparation and characterization of self-assemblied nanoparticles based on folic acid modified carboxymethyl chitosan, J. Mater. Sci. Mater. Med. 22 (2011) 1213-1220.

[103] S. Maya, S. Indulekha, V. Sukhithasri, K.T. Smitha, S.V. Nair, R. Jayakumar, R. Biswas, Efficacy of tetracycline encapsulated $O$-carboxymethyl chitosan nanoparticles against intracellular infections of Staphylococcus aureus, Int. J. Biol. Macromol. 51 (2012) 392-399.

[104] K.S. Snima, R. Jayakumar, A.G. Unnikrishnan, S.V. Nair, V.-K. Lakshmanan, Ocarboxymethyl chitosan nanoparticles for metformin delivery to pancreatic cancer cells, Carbohydr. Polym. 89 (2012) 1003-1007.

[105] A. Anitha, K.P. Chennazhi, S.V. Nair, R. Jayakumar, 5-Flourouracil loaded N,Ocarboxymethyl chitosan nanoparticles as an anticancer nanomedicine for breast cancer, J. Biomed. Nanotechnol. 8 (2012) 29-42.

[106] J. Ji, S. Hao, J. Dong, D. Wu, B. Yang, Y. Xu, Preparation, evaluation, and in vitro release study of $O$-carboxymethyl chitosan nanoparticles loaded with gentamicin and salicylic acid, J. Appl. Polym. Sci. 123 (2012) 1684-1689.

[107] Z. Teng, Y. Luo, Q. Wang, Carboxymethyl chitosan-soy protein complex nanoparticles for the encapsulation and controlled release of vitamin D3, Food Chem. 141 (2013) 524-532.

[108] L. Zhao, B. Zhu, Y. Jia, W. Hou, C. Su, Preparation of biocompatible carboxymethyl chitosan nanoparticles for delivery of antibiotic drug, Biomed. Res. Int. 2013 (2013).

[109] K.S. Snima, R. Jayakumar, V.K. Lakshmanan, In vitro and in vivo biological evaluation of 0 -carboxymethyl chitosan encapsulated metformin nanoparticles for pancreatic cancer therapy, Pharm. Res. 31 (2014) 3361-3370.

[110] Y.-C. Huang, T.-H. Kuo, O-carboxymethyl chitosan/fucoidan nanoparticles increase cellular curcumin uptake, Food Hydrocoll. 53 (2016) 261-269.

[111] Y. Zu, Y. Zhang, W. Wang, X. Zhao, X. Han, K. Wang, Y. Ge, Preparation and in vitro/ in vivo evaluation of resveratrol-loaded carboxymethyl chitosan nanoparticles, Drug Deliv. 23 (2016) 971-981.

[112] F.O.M.S. Abreu, C. Bianchini, T.B. Kistb, M.M.C. Fortea, Preparation and properties of core-shell alginate-carboxymethylchitosan hydrogels, Polym. Int. 58 (2009) 1267-1274.

[113] R. Sari, M. Magda, W. Lestari, M.A.S. Rijal, Ketoprofen-carboxymethyl chitosan microparticles prepared by spray drying: Optimization and evaluation, Asian J. Pharm. Clin. Res. 8 (2015) 331-333.

[114] Y. Mi, R. Su, D.-D. Fan, X.-L. Zhu, W.-N. Zhang, Preparation of N,O-carboxymethyl chitosan coated alginate microcapsules and their application to Bifidobacterium longum BIOMA 5920, Mater. Sci. Eng. C 33 (2013) 3047-3053.

[115] D. Yang, X. Gao, J. Qiao, J. Nie, Genipin-crosslinked N-carboxymethyl chitosan microcapsules prepared by electrostatic spray method, J. Control. Release 152 (Suppl. 1) (2011) e252-e253.

[116] L.M. Zhou, Y.P. Wang, Q.W. Huang, Z.R. Liu, Preparation and characterization of carboxymethyl chitosan magnetic nanoparticles, Gaofenzi Cailiao Kexue Yu Gongcheng/Polymeric Materials Science and Engineering 24 (2008) 143-146.

[117] A. Zhu, L. Yuan, W. Jin, S. Dai, Q. Wang, Z. Xue, A. Qin, Polysaccharide surface modified Fe3O4 nanoparticles for camptothecin loading and release, Acta Biomater. 5 (2009) 1489-1498

[118] T. Chen, R. Wang, L.Q. Xu, K.G. Neoh, E.T. Kang, Carboxymethyl chitosanfunctionalized magnetic nanoparticles for disruption of biofilms of staphylococcus aureus and escherichia coli, Ind. Eng. Chem. Res. 51 (2012) 13164-13172.

[119] R. Lamim, R.A. de Freitas, E.I. Rudek, H.M. Wilhelm, O.A. Cavalcanti, T.M.B. Bresolin, Films of chitosan and $N$-carboxymethyl-chitosan. Part II: effect of plasticizers on their physiochemical properties, Polym. Int. 55 (2006) 970-977.

[120] L.C. Wang, X.G. Chen, L.J. Yu, P.W. Li, Controlled drug release through carboxymethylchitosan/poly(vinyl alcohol) blend films, Polym. Eng. Sci. 47 (2007) 1373-1379.

[121] L.C. Wang, X.G. Chen, D.Y. Zhong, O.C. Xu, Study on poly(vinyl alcohol)/ carboxymethyl-chitosan blend film as local drug delivery system, J. Mater. Sci. Mater. Med. 18 (2007) 1125-1133.

[122] B.I. Guo, J.F. Yuan, Q.Y. Gao, pH and ionic sensitive chitosan/carboxymethyl chitosan IPN complex films for the controlled release of coenzyme A, Colloid Polym. Sci. 286 (2008) 175-181.

[123] X.H. Zhao, X.W. He, S.Q. Xie, L.S. Yang, Preparation and properties of sodium carboxymethyl cellulose-hyaluronic acid-carboxymethyl chitosan blend, Applied Mechanics and Materials, Trans Tech Publ 2010, pp. 1157-1161. 
[124] P. Martins, M. Daga, C.F. Zandonai, B.S. Grandi, A.B. Cruz, R.M. Lucinda Silva, C.A Rodrigues, Release of tetracycline from $O$-carboxymethylchitosan films, Pharm. Dev. Technol. 16 (2011) 179-186.

[125] N.K. Patel, J. Joshi, D. Mishra, V.A. Patel, V.K. Sinha, Controlled release of carbamazepine from carboxymethyl chitosan-grafted-2-hydroxyethylmethacrylate matrix tablets, J. Appl. Polym. Sci. 115 (2010) 3442-3450.

[126] Hernawan, S. Nurhayati, K. Nisa, A.W. Indrianingsih, C. Darsih, M. Kismurtono, Formulation and in vitro study of propranolol hydrochloride controlled release from carboxymethyl chitosan-based matrix tablets, Indones. J. Chem. 13 (2013) 242-247.

[127] J.R. Bresolin, M.-C.T. Largura, C.C. Dalri, G. Hoffer, C.A. Rodrigues, R.M. Lucinda-Silva, Spray-dried $O$-carboxymethyl chitosan as potential hydrophilic matrix tablet for sustained release of drug, Drug Dev. Ind. Pharm. 40 (2014) 503-510.

[128] J.P. Rao, K.E. Geckeler, Polymer nanoparticles: preparation techniques and sizecontrol parameters, Prog. Polym. Sci. 36 (2011) 887-913.

[129] S.C. Gad, Pharmaceutical Manufacturing Handbook: Production and Processes, Wiley, Hoboken, 2008.

[130] M. Vert, Y. Doi, K.H. Hellwich, M. Hess, P. Hodge, P. Kubisa, M. Rinaudo, F. Schué, Terminology for biorelated polymers and applications (IUPAC recommendations 2012), Pure Appl. Chem. 84 (2012) 377-410.

[131] F.S. Poletto, R.C.R. Beck, S.S. Guterres, A.R. Pohlmann, Polymeric nanocapsules: concepts and applications, in: R. Beck, S. Guterres, A. Pohlmann (Eds.), Nanocosmetics and Nanomedicines: New Approaches for Skin Care, Springer Berlin Heidelberg, Berlin, Heidelberg 2011, pp. 49-68.

[132] B. Fonseca-Santos, M.P. Gremiao, M. Chorilli, Nanotechnology-based drug delivery systems for the treatment of Alzheimer's disease, Int. J. Nanomedicine 10 (2015) 4981-5003.

[133] P. Couvreur, G. Barratt, E. Fattal, P. Legrand, C. Vauthier, Nanocapsule technology: a review, Crit. Rev. Ther. Drug Carrier Syst. 19 (2002) 99-134.

[134] L. Wang, Y. Liu, W. Zhang, X. Chen, T. Yang, G. Ma, Microspheres and microcapsules for protein delivery: strategies of drug activity retention, Curr. Pharm. Des. 19 (2013) 6340-6352.

[135] N.K. Varde, D.W. Pack, Microspheres for controlled release drug delivery, Expert. Opin. Biol. Ther. 4 (2004) 35-51.

[136] T. Akagi, M. Baba, M. Akashi, Preparation of nanoparticles by the self-organization of polymers consisting of hydrophobic and hydrophilic segments: potential applications, Polymer 48 (2007) 6729-6747.

[137] V.R. Tirumala, G.T. Caneba, Y. Dar, H.-H. Wang, D.C. Mancini, Nanoparticles from a controlled polymerization process, Adv. Polym. Technol. 22 (2003) 126-136.

[138] Y. Dong, W.K. Ng, S. Shen, S. Kim, R.B.H. Tan, Scalable ionic gelation synthesis of chitosan nanoparticles for drug delivery in static mixers, Carbohydr. Polym. 94 (2013) 940-945.

[139] R. Yoksan, J. Jirawutthiwongchai, K. Arpo, Encapsulation of ascorbyl palmitate in chitosan nanoparticles by oil-in-water emulsion and ionic gelation processes, Colloids Surf. B: Biointerfaces 76 (2010) 292-297.

[140] R.M. Mainardes, R.C. Evangelista, Praziquantel-loaded PLGA nanoparticles: preparation and characterization, J. Microencapsul. 22 (2005) 13-24.

[141] A. Alshamsan, Nanoprecipitation is more efficient than emulsion solvent evaporation method to encapsulate cucurbitacin I in PLGA nanoparticles, Saudi Pharm. J. 22 (2014) 219-222.

[142] L. Qian, A. Ahmed, H. Zhang, Formation of organic nanoparticles by solvent evaporation within porous polymeric materials, Chem. Commun. 47 (2011) 10001-10003.

[143] X.-y. Jiang, C.-s. Zhou, K.-w. Tang, Preparation of PLA and PLGA nanoparticles by binary organic solvent diffusion method, J. Cent. S. Univ. Technol. 10 (2003) 202-206.

[144] H. Murakami, M. Kobayashi, H. Takeuchi, Y. Kawashima, Preparation of poly(D,Llactide-co-glycolide) nanoparticles by modified spontaneous emulsification solvent diffusion method, Int. J. Pharm. 187 (1999) 143-152.

[145] A. Gharsallaoui, G. Roudaut, O. Chambin, A. Voilley, R. Saurel, Applications of spraydrying in microencapsulation of food ingredients: an overview, Food Res. Int. 40 (2007) 1107-1121.

[146] K. Byrappa, S. Ohara, T. Adschiri, Nanoparticles synthesis using supercritical fluid technology-towards biomedical applications, Adv. Drug Deliv. Rev. 60 (2008) 299-327.

[147] R.M. Obaidat, B.M. Tashtoush, M.F. Bayan, R.T. Al Bustami, M. Alnaief, Drying using supercritical fluid technology as a potential method for preparation of chitosan aerogel microparticles, AAPS PharmSciTech 16 (2015) 1235-1244.

[148] A.R.C. Duarte, M.S. Costa, A.L. Simplício, M.M. Cardoso, C.M.M. Duarte, Preparation of controlled release microspheres using supercritical fluid technology for delivery of anti-inflammatory drugs, Int. J. Pharm. 308 (2006) 168-174.

[149] J. Xu, D.H.C. Wong, J.D. Byrne, K. Chen, C. Bowerman, J.M. DeSimone, Future of the particle replication in nonwetting templates (PRINT) technology, Angew. Chem. Int. Ed. 52 (2013) 6580-6589.

[150] G.R. Robbins, R.A. Roberts, H. Guo, K. Reuter, T. Shen, G.D. Sempowski, K.P. McKinnon, L. Su, J.M. DeSimone, J.P.Y. Ting, Analysis of human innate immune responses to PRINT fabricated nanoparticles with cross validation using a humanized mouse model, Nanomed. Nanotechnol. Biol. Med. 11 (2015) 589-599.
[151] L.E. Roode, H. Brighton, T. Bo, J.L. Perry, M.C. Parrott, F. Kersey, J.C. Luft, J.E. Bear, J.M. DeSimone, I.J. Davis, Subtumoral analysis of PRINT nanoparticle distribution reveals targeting variation based on cellular and particle properties, Nanomed. Nanotechnol. Biol. Med. 12 (2016) 1053-1062.

[152] A.L. Galloway, A. Murphy, J.M. DeSimone, J. Di, J.P. Herrmann, M.E. Hunter, J.P. Kindig, F.J. Malinoski, M.A. Rumley, D.M. Stoltz, T.S. Templeman, B. Hubby, Development of a nanoparticle-based influenza vaccine using the PRINT® technology, Nanomed. Nanotechnol. Biol. Med. 9 (2013) 523-531.

[153] L. Upadhyaya, J. Singh, V. Agarwal, R.P. Tewari, Biomedical applications of carboxymethyl chitosans, Carbohydr. Polym. 91 (2013) 452-466.

[154] S. Kalasin, J. Dabkowski, K. Nüsslein, M.M. Santore, The role of nano-scale heterogeneous electrostatic interactions in initial bacterial adhesion from flow: a case study with Staphylococcus aureus, Colloids Surf. B: Biointerfaces 76 (2010) 489-495.

[155] S. Perni, E.C. Preedy, P. Prokopovich, Success and failure of colloidal approaches in adhesion of microorganisms to surfaces, Adv. Colloid Interf. Sci. 206 (2014) 265-274.

[156] G. Hwang, I.-S. Ahn, B.J. Mhin, J.-Y. Kim, Adhesion of nano-sized particles to the surface of bacteria: mechanistic study with the extended DLVO theory, Colloids Surf B: Biointerfaces 97 (2012) 138-144.

[157] L. Sun, Y. Du, L. Fan, X. Chen, J. Yang, Preparation, characterization and antimicrobial activity of quaternized carboxymethyl chitosan and application as pulp-cap, Polymer 47 (2006) 1796-1804.

[158] L. Ilium, Chitosan and its use as a pharmaceutical excipient, Pharm. Res. 15 (1998) $1326-1331$

[159] J.D. Smart, The basics and underlying mechanisms of mucoadhesion, Adv. Drug Deliv. Rev. 57 (2005) 1556-1568.

[160] F.C. Carvalho, M.L. Bruschi, R.C. Evangelista, M.P.D. Gremião, Mucoadhesive drug delivery systems, Braz. J. Pharm. Sci. 46 (2010) 1-17.

[161] F.C. Carvalho, M. Chorilli, M.P.D. Gremião, Plataformas bio(muco) adesivas poliméricas baseadas em nanotecnologia para liberação controlada de fármacos-propriedades, metodologias e aplicações, Polímeros 24 (2014) 203-213.

[162] R. Shaikh, T.R.R. Singh, Martin James Garland, A.D. Woolfson, R.F. Donnelly Mucoadhesive drug delivery systems, J. Pharm. Bioallied Sci. 3 (2011) 89-100.

[163] S. Chopra, S. Mahdi, J. Kaur, Z. Iqbal, S. Talegaonkar, F.J. Ahmad, Advances and potential applications of chitosan derivatives as mucoadhesive biomaterials in modern drug delivery, J. Pharm. Pharmacol. 58 (2006) 1021-1032.

[164] M. Bodmer, P. Vankan, M. Dreier, K.W. Kutz, J. Drewe, Pharmacokinetics and metabolism of idebenone in healthy male subjects, Eur. J. Clin. Pharmacol. 65 (2009) 493-501.

[165] V.V. Mody, A. Cox, S. Shah, A. Singh, W. Bevins, H. Parihar, Magnetic nanoparticle drug delivery systems for targeting tumor, Appl. Nanosci. 4 (2014) 385-392.

[166] J.R. McCarthy, R. Weissleder, Multifunctional magnetic nanoparticles for targeted imaging and therapy, Adv. Drug Deliv. Rev. 60 (2008) 1241-1251.

[167] J. Chomoucka, J. Drbohlavova, D. Huska, V. Adam, R. Kizek, J. Hubalek, Magnetic nanoparticles and targeted drug delivering. Pharmacol. Res. 62 (2010) 144-149.

[168] A.M. Saetern, G.E. Flaten, M. Brandl, A method to determine the incorporation capacity of camptothecin in liposomes, AAPS PharmSciTech 5 (2004), e40.

[169] M. Gibaldi, S. Feldman, Establishment of sink conditions in dissolution rate determinations. Theoretical considerations and application to nondisintegrating dosage forms, J. Pharm. Sci. 56 (1967) 1238-1242.

[170] V.P. Shah, J.J. Konecny, R.L. Everett, B. McCullough, A.C. Noorizadeh, J.P. Skelly, In vitro dissolution profile of water-insoluble drug dosage forms in the presence of surfactants, Pharm. Res. 6 (1989) 612-618.

[171] T. Incecayir, The effects of surfactants on the solubility and diolution profiles of a poorly water-soluble basic drug, carvedilol, Pharmazie 70 (2015) 784-790.

[172] M. Siewert, J. Dressman, C.K. Brown, V.P. Shah, J.M. Aiache, N. Aoyagi, D. Bashaw, C. Brown, W. Brown, D. Burgess, J. Crison, P. DeLuca, R. Djerki, T. Foster, K. Gjellan, V. Gray, A. Hussain, T. Ingallinera, J. Klancke, J. Kraemer, H. Kristensen, K. Kumi, C. Leuner, J. Limberg, P. Loos, L. Margulis, P. Marroum, H. Moeller, B. Mueller, M. Mueller-Zsigmondy, N. Okafo, L. Ouderkirk, S. Parsi, S. Qureshi, J. Robinson, V. Shah, R. Uppoor, R. Williams, FIP/AAPS guidelines to dissolution/in vitro release testing of novel/special dosage forms, AAPS PharmSciTech 4 (2003) 43-52.

[173] P. Borgquist, A. Körner, L. Piculell, A. Larsson, A. Axelsson, A model for the drug release from a polymer matrix tablet-effects of swelling and dissolution, J. Control. Release 113 (2006) 216-225.

[174] P. Colombo, Modern hydrogel delivery systems swelling-controlled release in hydrogel matrices for oral route, Adv. Drug Deliv. Rev. 11 (1993) 37-57.

[175] P. Colombo, R. Bettini, P. Santi, N.A. Peppas, Swellable matrices for controlled drug delivery: gel-layer behaviour, mechanisms and optimal performance, Pharm. Sci. Technol. Today 3 (2000) 198-204.

[176] J. Siepmann, N.A. Peppas, Modeling of drug release from delivery systems based on hydroxypropyl methylcellulose (HPMC), Adv. Drug Deliv. Rev. 48 (2001) 139-157.

[177] C. Maderuelo, A. Zarzuelo, J.M. Lanao, Critical factors in the release of drugs from sustained release hydrophilic matrices, J. Control. Release 154 (2011) 2-19. 